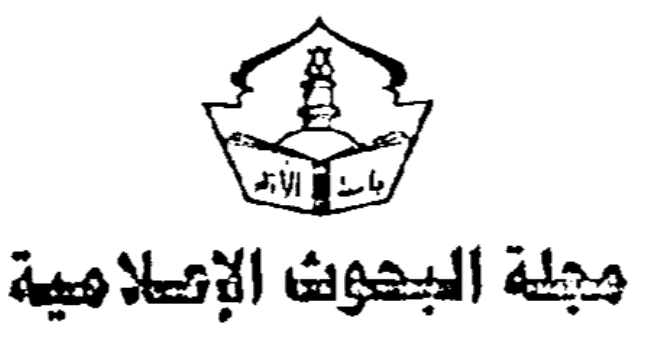

مجلة علعية مدكمة تصدر عن جامعة الأزهر

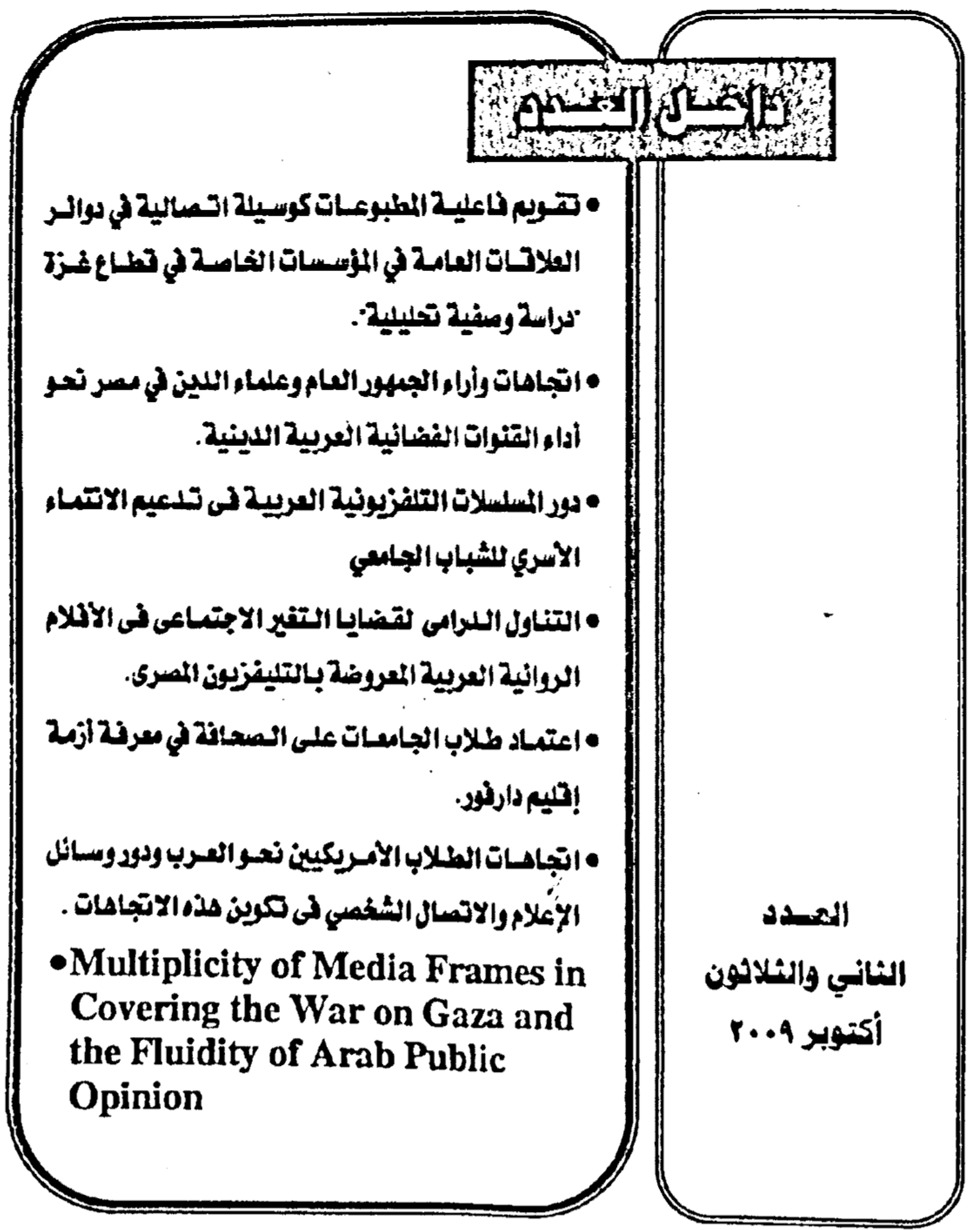




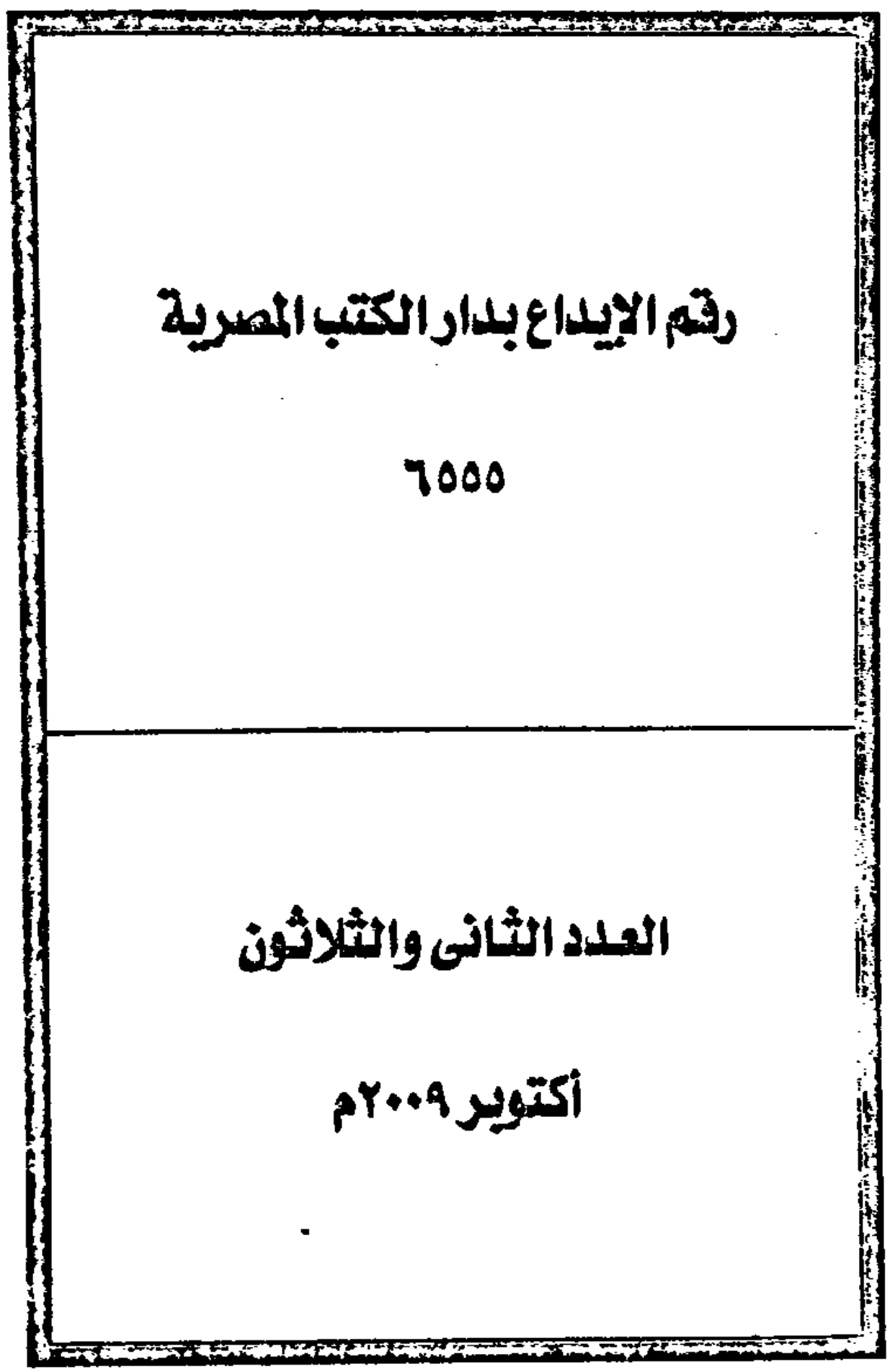




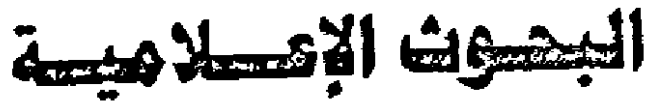

دورية علمية محكمة تصدر عن جامعة الأزهر

رئيس مجلس الإدارة

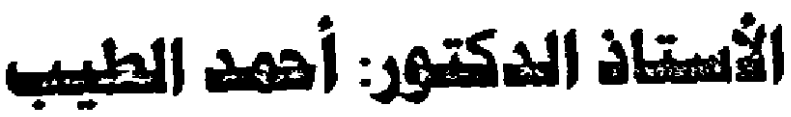

$$
\text { رئيس التحرير }
$$

أ. ه: مهيم الدين كبد الحبيم

$$
\text { مدير التحرير }
$$

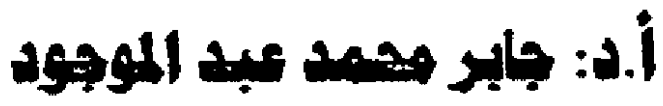

$$
\text { الإسـراف الفني }
$$

أ.د: بسامي عبد العزيز الكوهي

$$
\text { سكرتيز التحرير }
$$

2/ مبد الراضي هشي البلبوشي

توجه باسم الدكتور سكرتير التحرير على العنوان التالى: جامعة الأزمر -

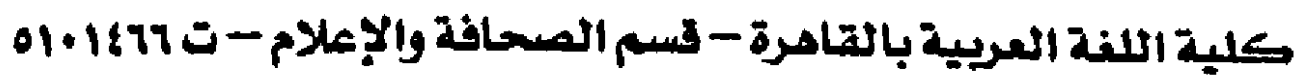




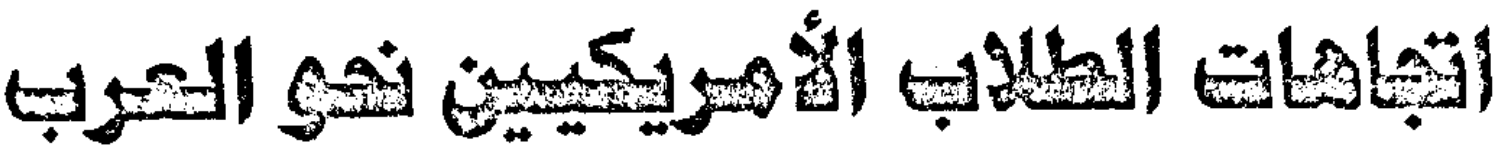

19:

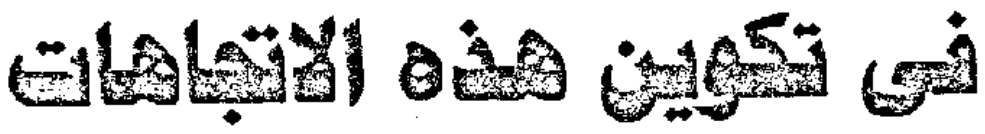

$$
\begin{aligned}
& 12
\end{aligned}
$$

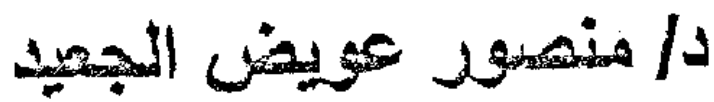

$$
\begin{aligned}
& \text { تسم الإعلاِم - كلية الآداب والططنم الإنساتية } \\
& \text { جامعة الملثك عبد التمزيز }
\end{aligned}
$$




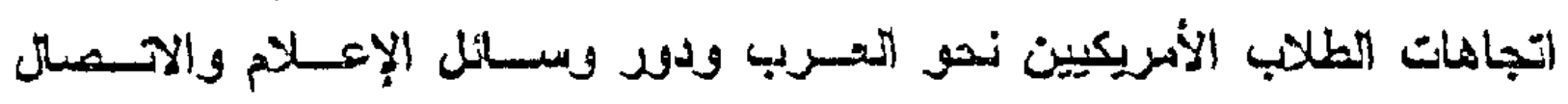
الشخخصي فى تكوين هذه الاحجاهات

\section{ملفص البحث:}

تهنف هذه النراسة إلى التعرن على الاتجاهات والصور الآهنية التهى يحطهـا

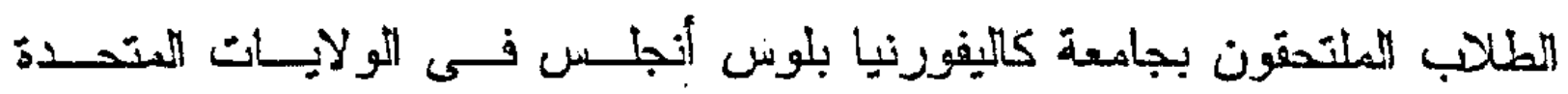
الأمريكية (UCLA) تجاه المربب والكثيف عن مدى الاختلاف فى هذه الاتجاهات

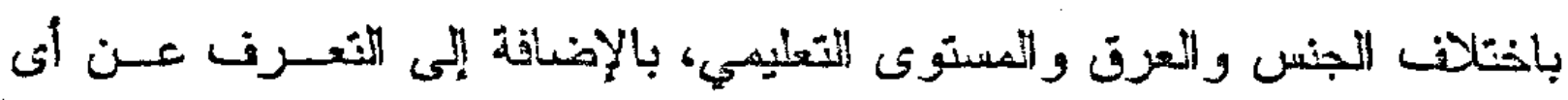

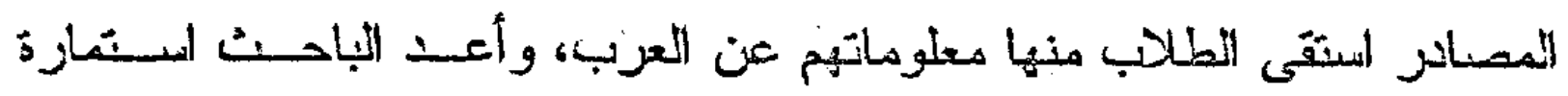
مكرنة هن · r صفحة وعكنها على مقياس ليكزت المكون من خمس مرجبات

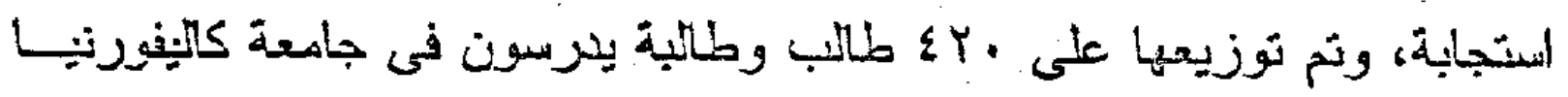

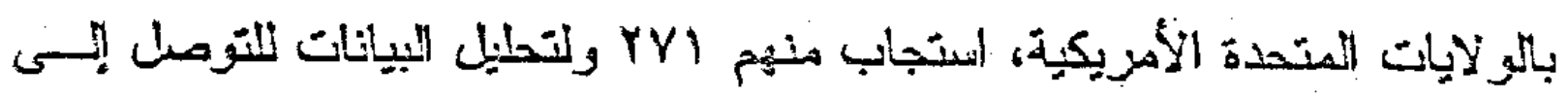

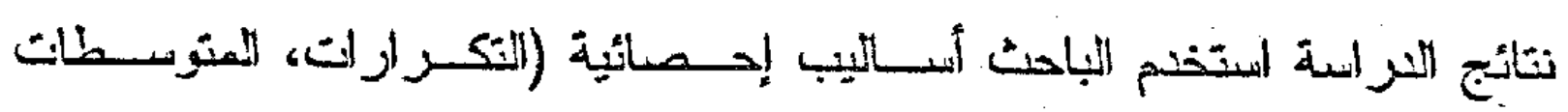

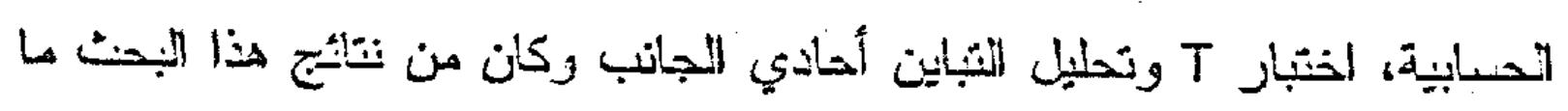
يلى:

ا- المسور الذهنية النى يحملها الطلاتب الأمزيكيين تجاه البزب فى معظمبا محايدة.

r- توجد فروق دالة الحصائيا فى اتجاهات الطلاب وفقاً لمتغير الجنس.

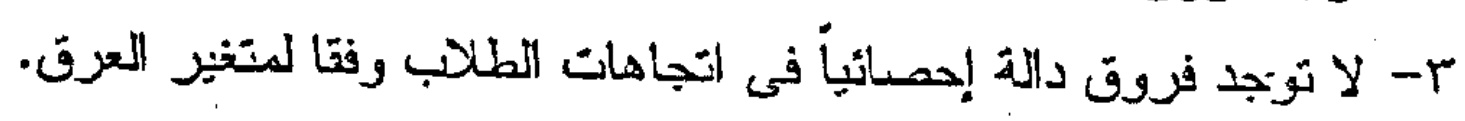

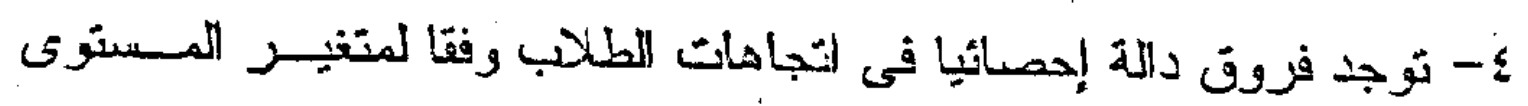
التعليمي (جِامعى، دراسات عليا). 
ه- توجد فروف دالة إحصائيا فى اتجاهات الطلابب وفقا لمتغيـر مـــادر المعلومات (المجلات، المحافة، الثلززيون، الاتصال الشخمىى). 


\section{هتبة}

تمبل الصورة النمطية Stereotype أحد الموضوعات المهمة فى عمل الـنفس

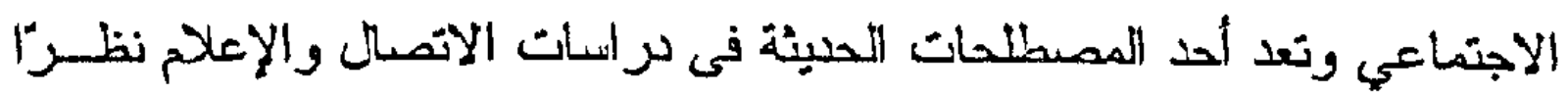

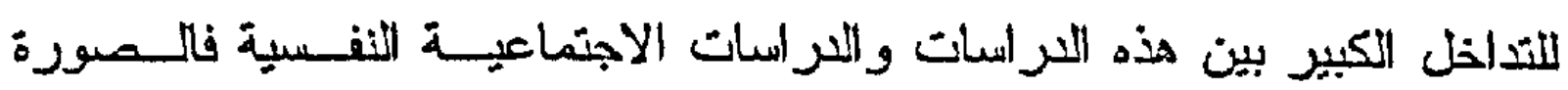
النمطية هى التى تتحكم فى علعاتتا وتعاملنا مع الآخرين كما أن لها أهمية كبرى فى العلحقات بين الأمم والشعوب.

لقد اكتببت الصمورة النمطية أهميتها في وسائل الإعلام نظرا للنور الكبيز والمهم

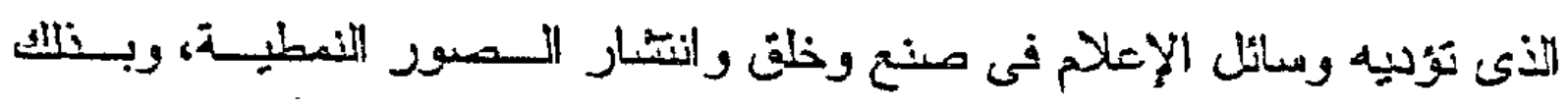

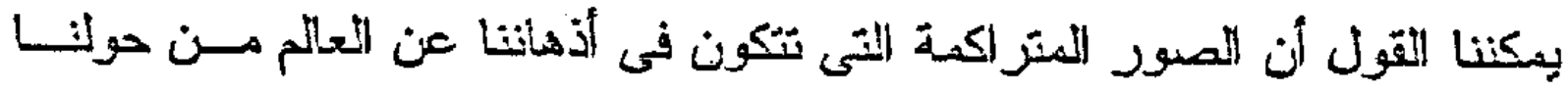

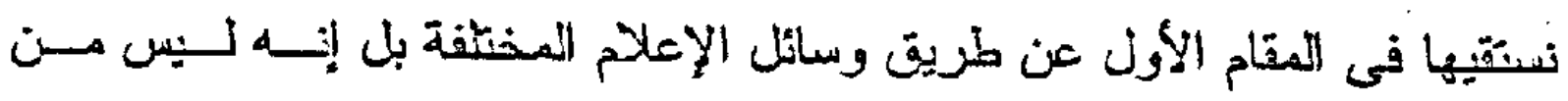

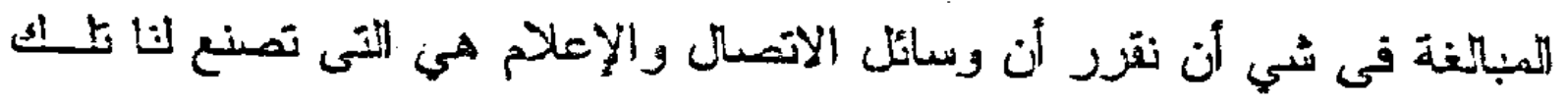

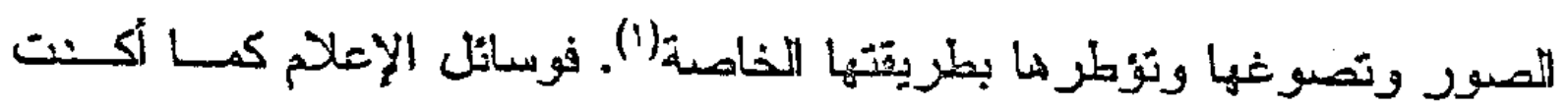

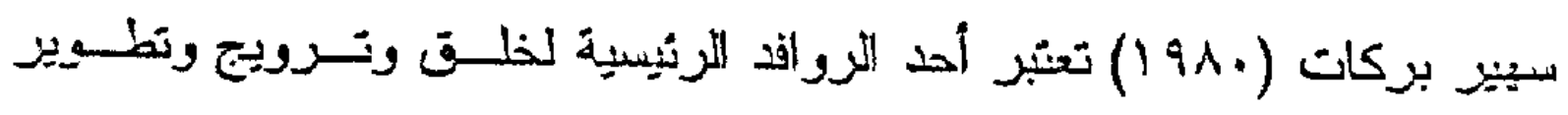

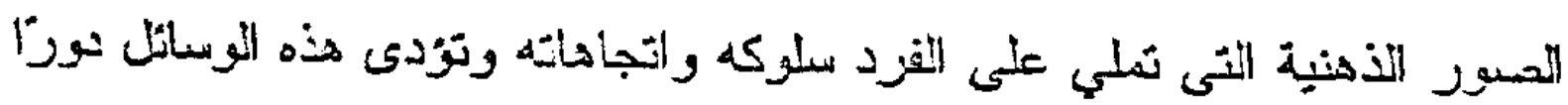

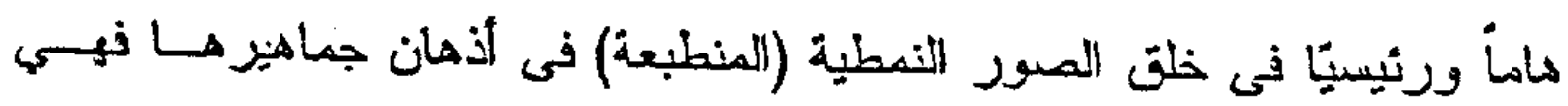
الامتذاد الطبيعى لأبصارنا وأسماعنا كما يقول مارشال ماكلوهن. وتزى سهير بركات أن هناك اختلاقًا بين الزسائل التى تبثنها وســائل الإعـلام والرسائل التى بتلقاها الثرد بطريقة مباشرة إذ أن وسائل الإعلام تعنمد فى معناها

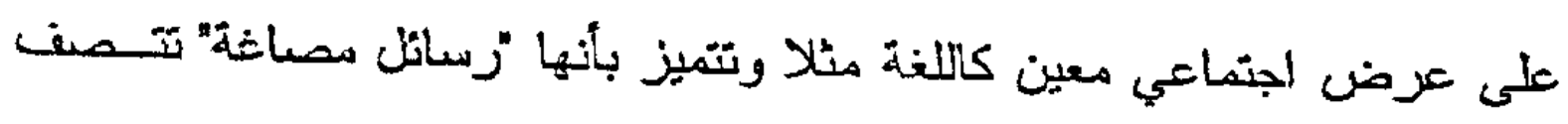
بالأحكام والتركيز وابعد عن الإسواب وتضيف ستير بركات أن وساثل الإعلام 
الجماهيرى لا تتوقف عند خلق الصور اللذهنية والأنماط لدى الجماهير بل إنهـ تقوم بطبع وتضضيم هذه الصور فى أذهانهم بلرجة كبيرة للزجة أن المتلى لهذه الوسائل بشعر في أكثر الأحيان أنه فعلا النتى بالشخصيات التى تثتاولها وســائل

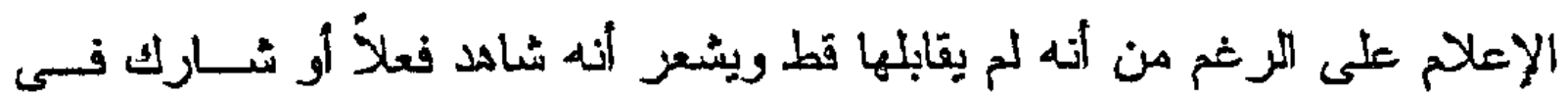

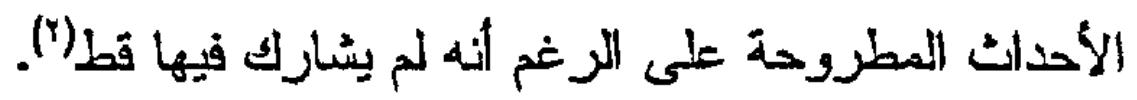

لقد بدأ الاهنمام بدراسة الصور النمطية فى العشرينات والتحالنينات مسـن القــرن Walter الماضى ويعود الفضل في نلك إلى ثلانثة من العلماء هم: وولتر ليبمان Stereptype الأى يعتبر أول من اثتبدع مصطلح الصور النمطيسة lippman

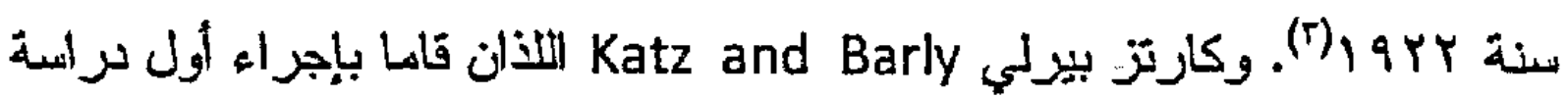

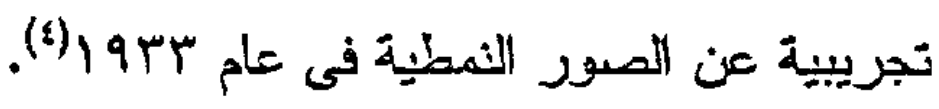

ولم يتنق كثير هن الباحثين والدارسين لمصطلح الصسور النمطيــة على ليجــاد مفهوم محند واضنح له فبعض الباحنين يستخنم كلمة "الصور الذهنية" والــبعض الآخز يطلت يليها كلمة "الصسور المقولبة" وفريق يستختم كلمة "الصور النمطية" ونرية رابع يطلق عليها "الصور المنطبعة"(o). Image ويزى روبنسون وبارلو أن هناك شبوأ كبيزا بين كلمتي الصور الأهنية والمور النمطية Stereptype لأنها ترنبطان بالتحيز للذي يعني الحكم المسبق

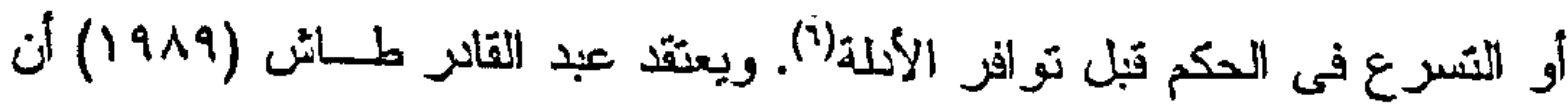
كلمتى (Image) و (Steretype) تشنركان فى دلالتوما على الصور الذهنبــة ويزى أن كلمة أعم وأشمل من كلمة Stereotype وهي قابلة للتغيــر 


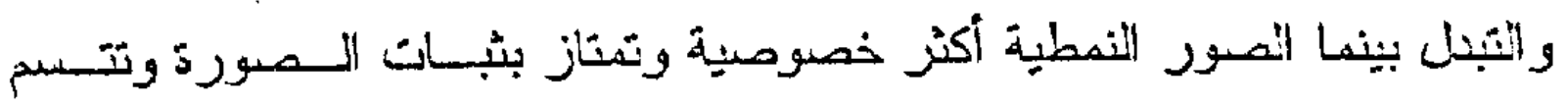
بالجمود و التبسيط المنزط (V)

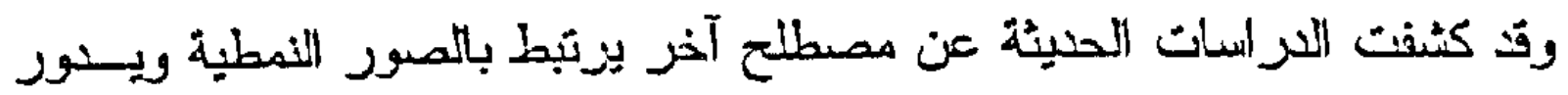
حول تصور شعب عن شععب آخر وهو ما يعرن بالــصور الذهنيسة القوميسـة وقد عرفه ميريل (National Image)

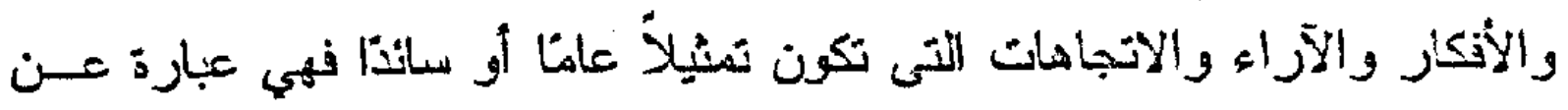

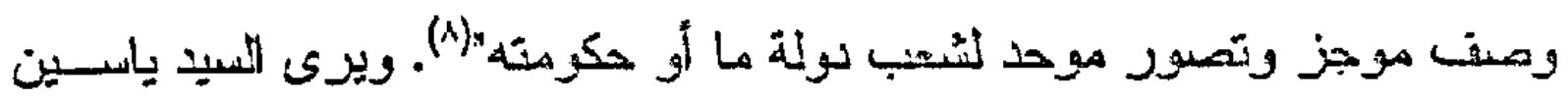

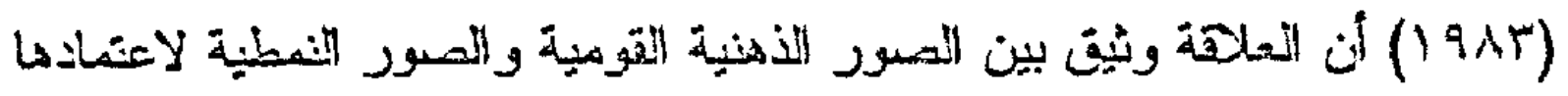

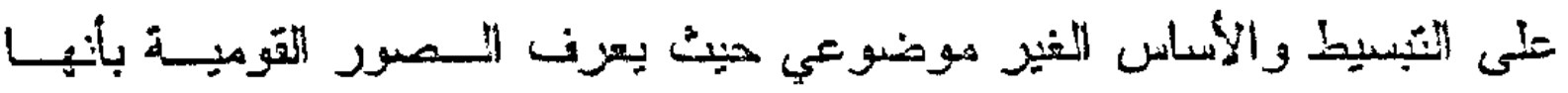

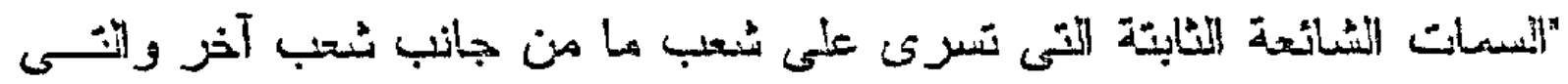

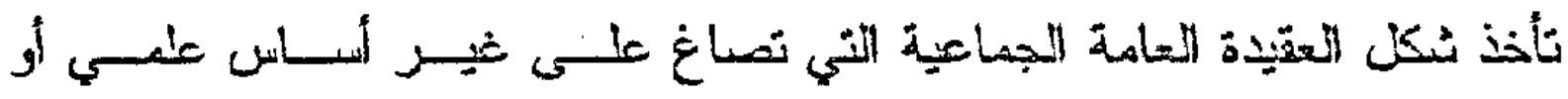

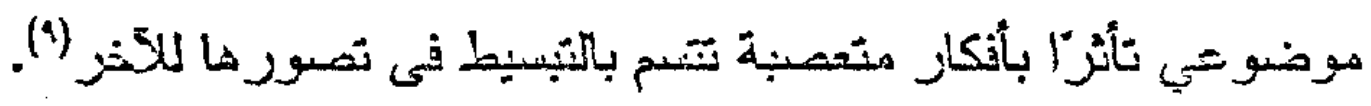

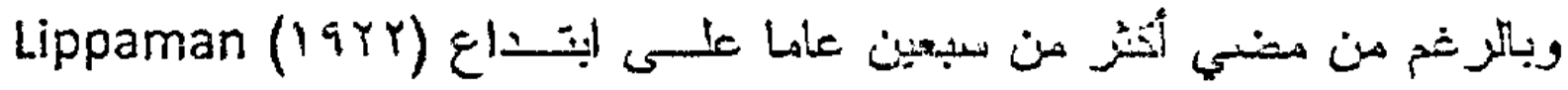

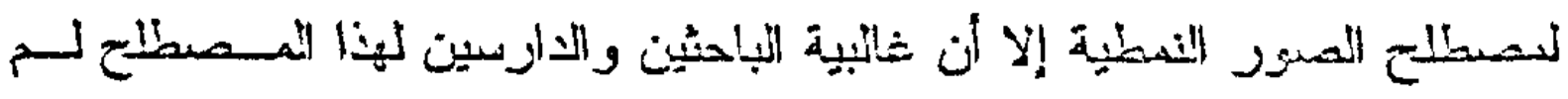

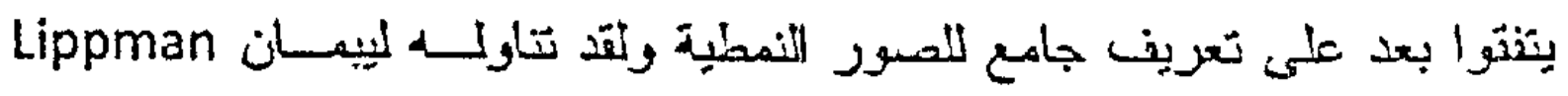

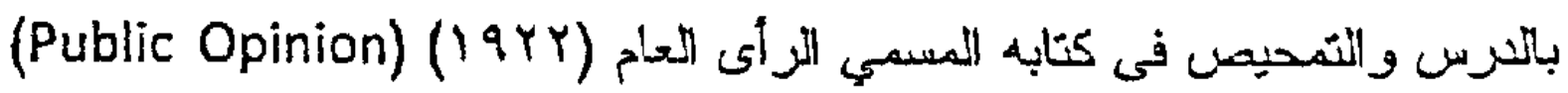
ومزن الصور النسطية بانها " صور موجودة فى أذهاننا" وهى إلطات تعميمات وأحكام عامة لمعلومات غيز مرغوبة أو خاطئة على أساس ما تحدده لنا ثقافاتتا

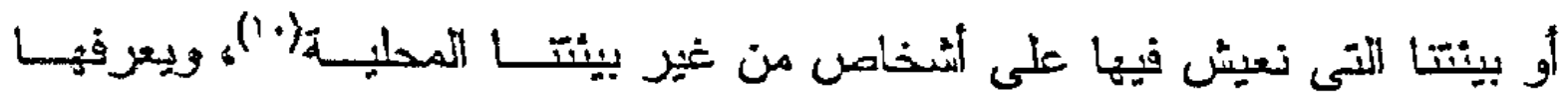

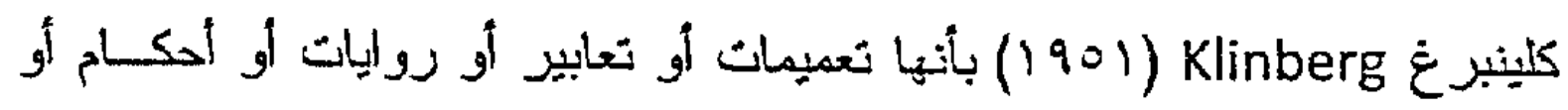


آراء تتعلق بمفات محدة لعرق أو جنس أو عنــر بـسرى وتعنمــد علـى هلويات غير دمَيقة وشائعات وحكايات نواير وأللة لا بكفي لتبرير إطلاق هذه (التحميمات على الجماعات (ii)

أما برغهام (9YY (1) فيعرف الصور النمطية بانها تعميم ســات فرنيــة غيـر مرغوبة ونسبها إلى أعضاء إلجماعات الأخرى('ا")، يقول هولستي (Holsti) فى تعريفه للصورة بأنها "مجموعة محارن القرد ومعثقداته فى الماضى والحاضــر والمسنتيل التى يحتظظ بيا الثزد وفقا لنظام معين عن ذاته وعن العالم للأى بعيش في (1T)

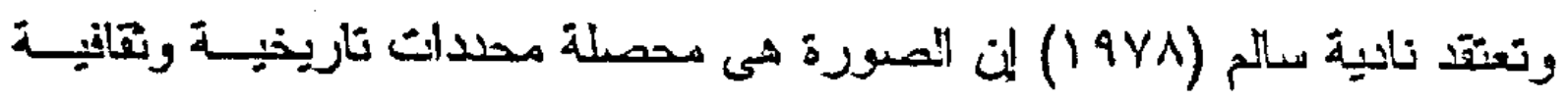
وسياسية واجتماعية ثير منفصلة عن التو القع ولا تيكسه فقط بل نتوم بنطوير تذا

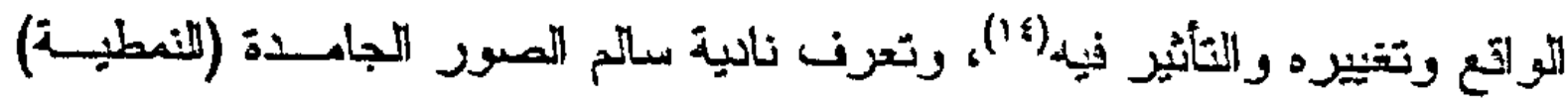
بأنبا "كيفية تصور شعب لسمات شعب آخر في ضوء تصبورات نمطية جامسدة

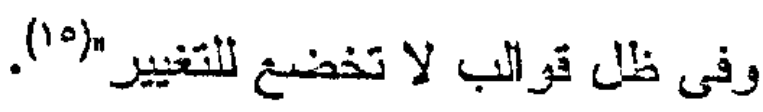

Webster's Dictionary (19V9) رالصور النمطية كما بعرفيا معجم ويبستر

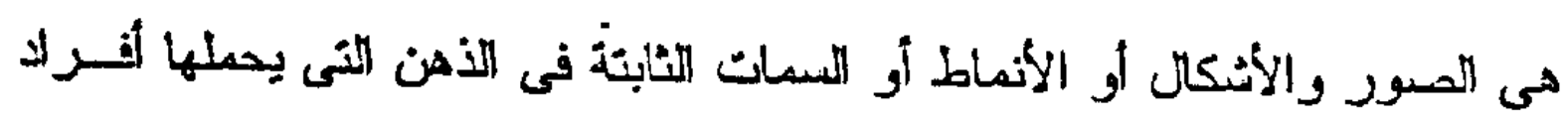
تجاه آخزين وتمنل رأيا مبسطو(1') وحيث أن الصور النمطية تعنمد على تعميمات سلبية أو غنر مرغوبة فهي أيضّا

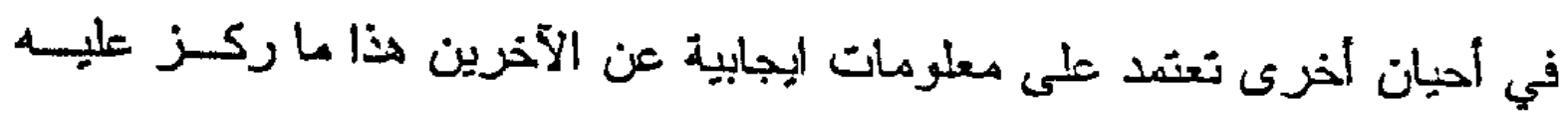

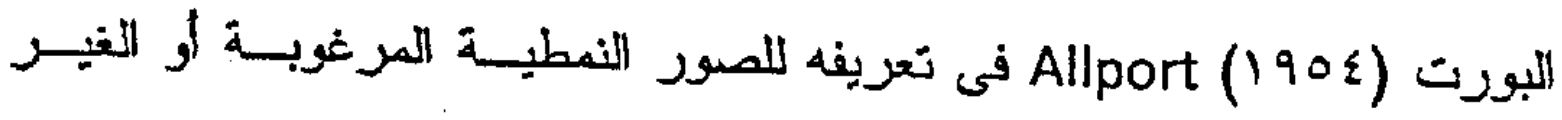




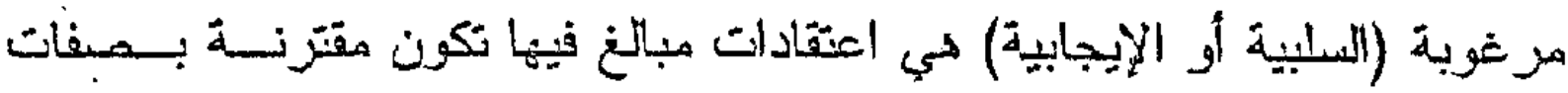

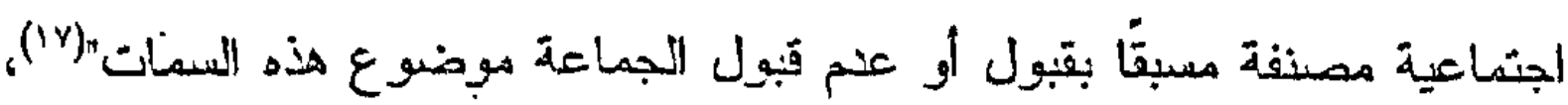

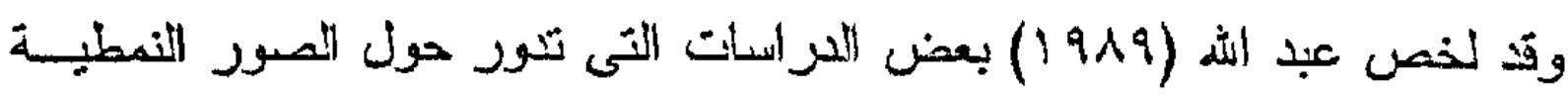

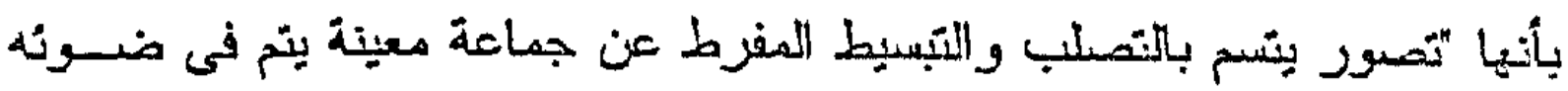
وصنس ونصنيفت الأشخاص النين ينتمون إلى هذه الجماعة بناء على مجمرعسة

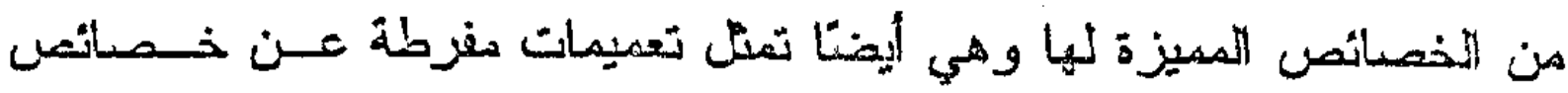
مجموعة من الأشخاص النين ينتهون إلى فئة لجنماعية معينة وعن المطرق التى يِبلكرن بمةنت-نشاها.

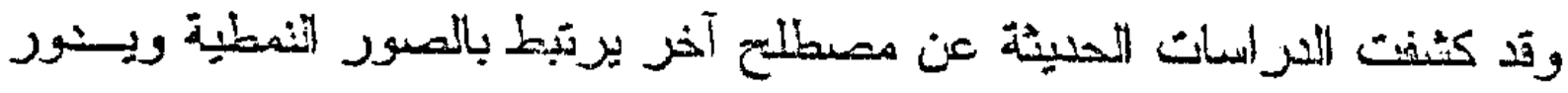

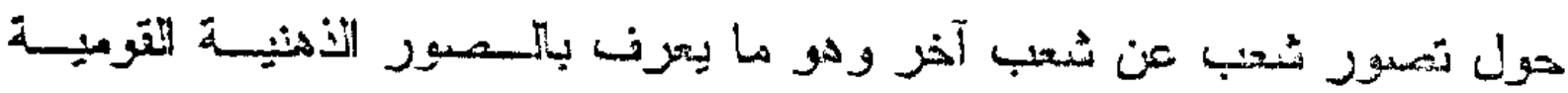

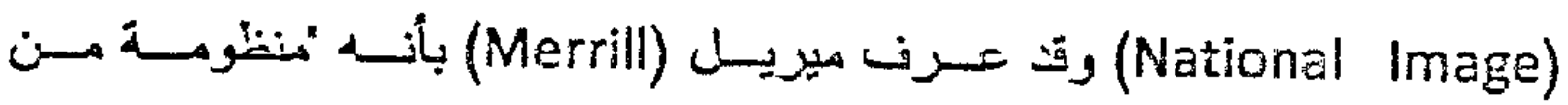

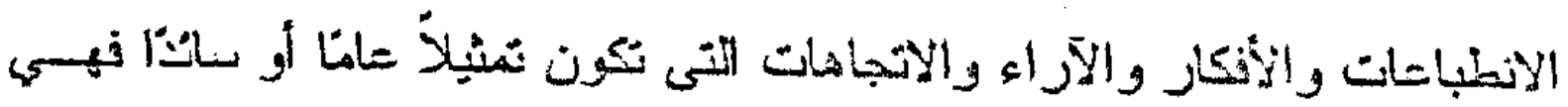

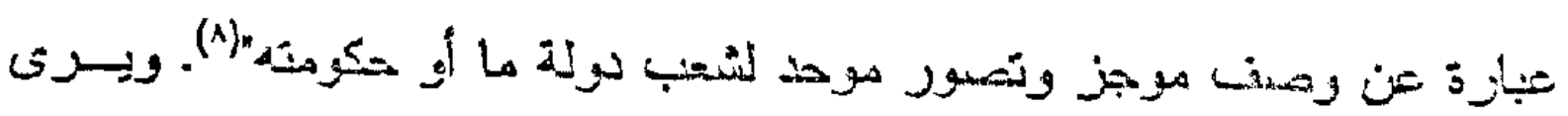

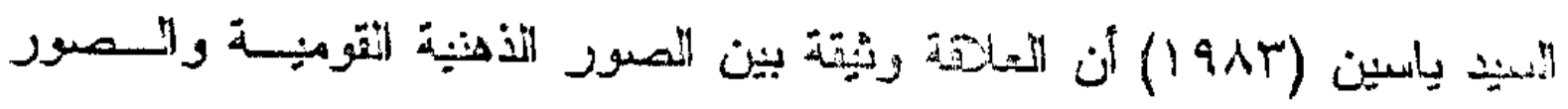
المنمطية لاعتدادها على النتبسيط والأساسل التخيز موضسوعي هنيث يعرن النسصور

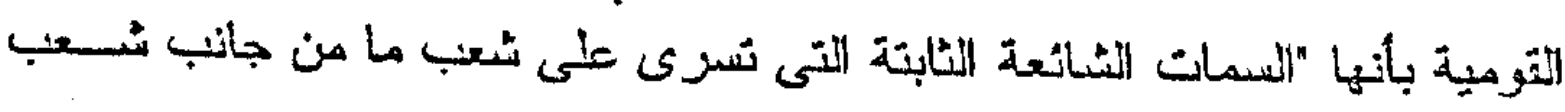

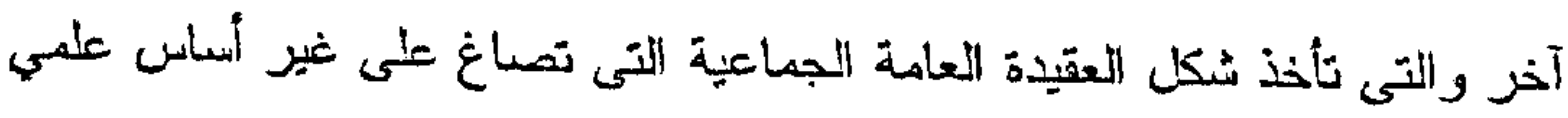

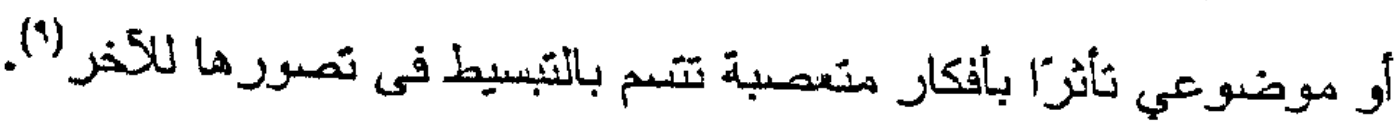

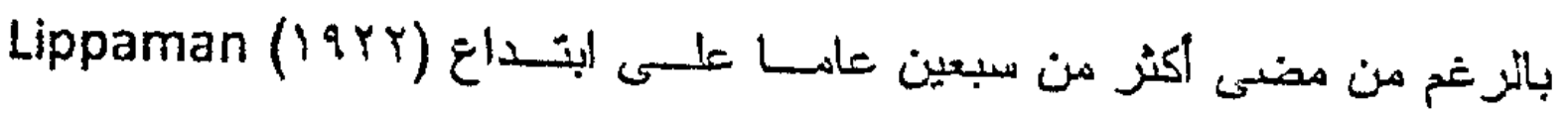

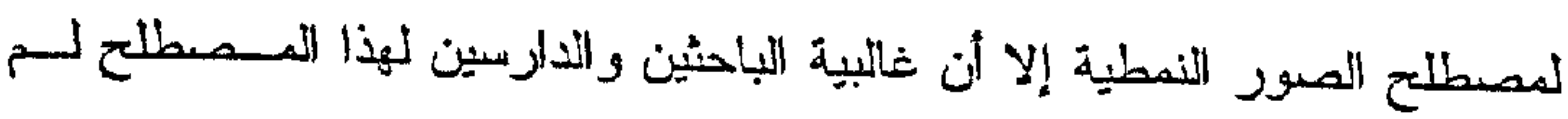




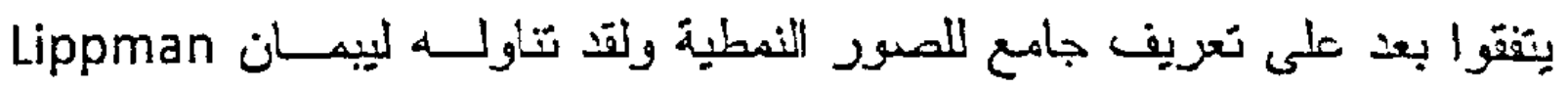

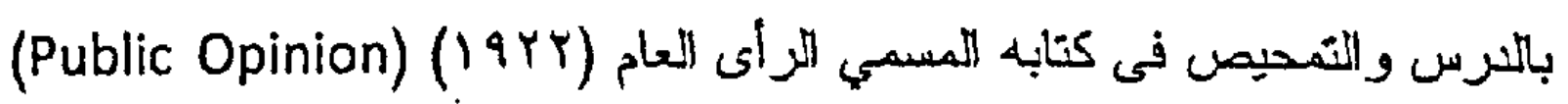
وعزن الصور النمطية بأنها "صور موجودة فى أذهانتا" وهى إطلات تعيمـات وأحكام عامة لمعلومات غير مرغوبة أو خاطثة على أساس ما تحلده لنا تقافاتا

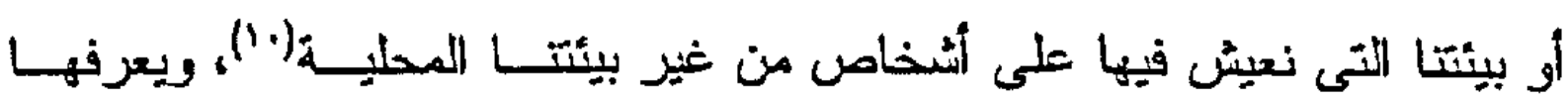
كلنيبرغ Klinberg (1901) بأنها تعميمات أو تعابيز أو روايات أو أحكام أو

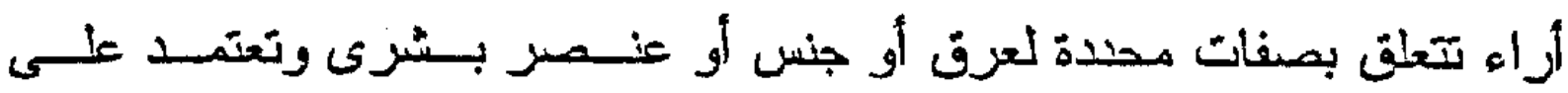
معلومات غير لتيقة وشائعات وحكايات نوالر وأنلة لا تكفى لتبرير إطلاق هذه (ii) التعميمات على الجماعات

أما برغهام (T (19VT) فيعرث الصور النمطية بأنها تعميم ســمات فرنبيسة غيسر

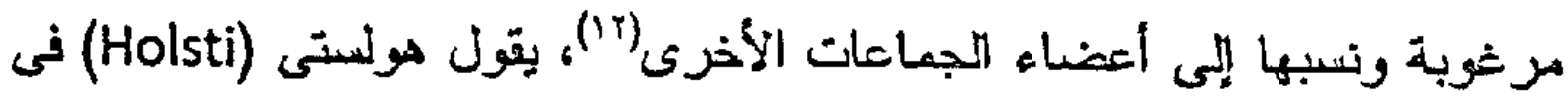
تعزينه للصورة بأنها "مجموعة معارن الغزد ومتثقداته فى الماضي والحاضــر

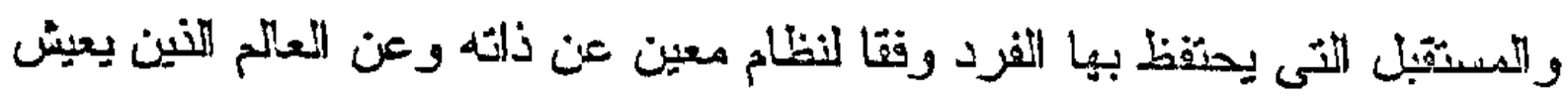
(iT)

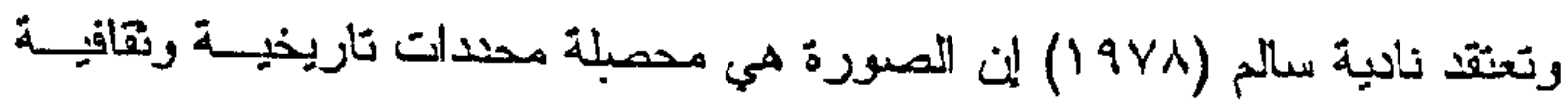

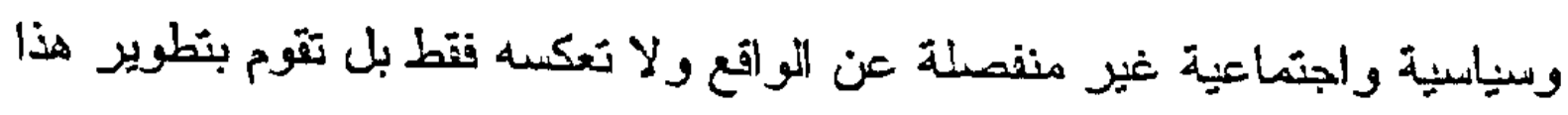

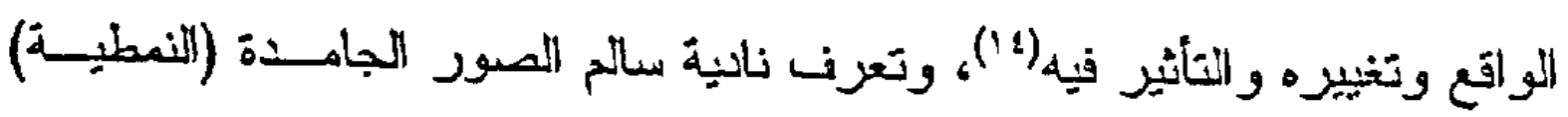

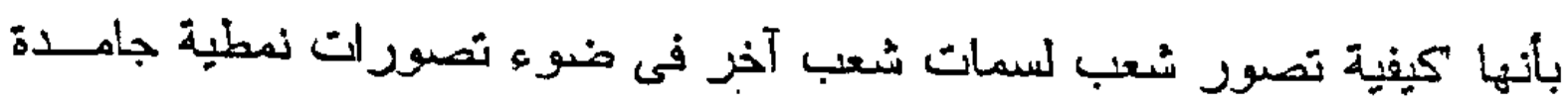
وفى ظل تو النب لا تخضع للتغيير" ب(10). 
والصور النمطية كما يعزفها معجم وييسنز (1979)

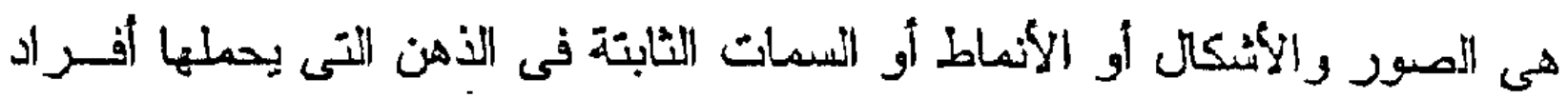

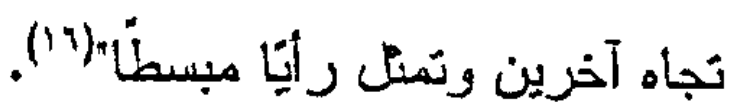

وحيث أن الصور إنتمطية تعتمد على تعميمات سلبية أو غير مرغوبة فهي أيضتا في أحيان أخرى تعتمد على معلومات ايجارية عن الآخرين هذا ما ركز عليسه

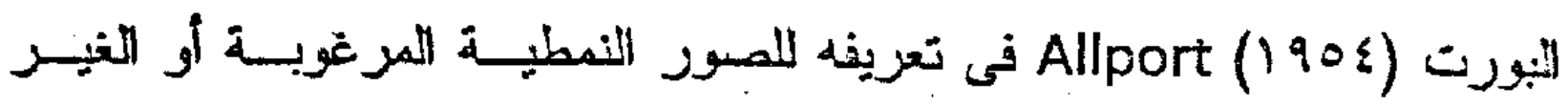
هرغوبة (السلبية أو الإيجابية) هى اعتقادات مبالغ فيها تكنون مقترنة بسمفات

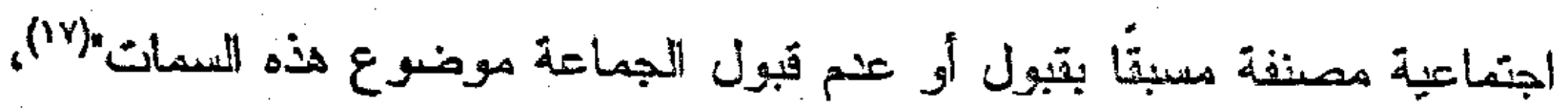

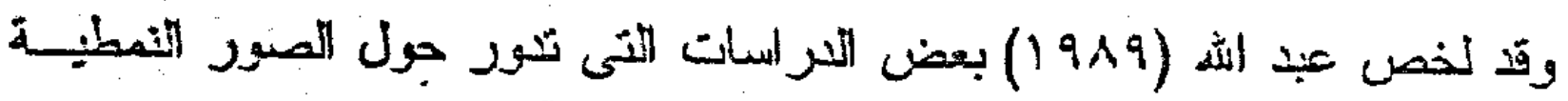
بأنها تصور يتسم بالنصلب والتبسيط المفرط عن جماعة معينة يتم في ضسئند وصف وتمنيف الأشخاص النين ينتمون إلى هذه الجماعة بناء على مجمو=سة هن الخصائص المميزة لوا.... وهى أيضتا تمثل تعميمات مفرطة عن خصائصل مجمويمة دن الأشخاص النين ينتمون إلى فئة اجنماعية معنية وعن لهرت التىى

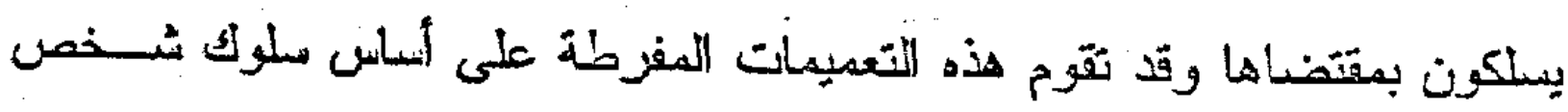

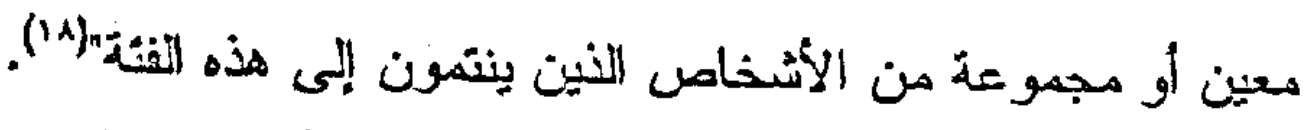

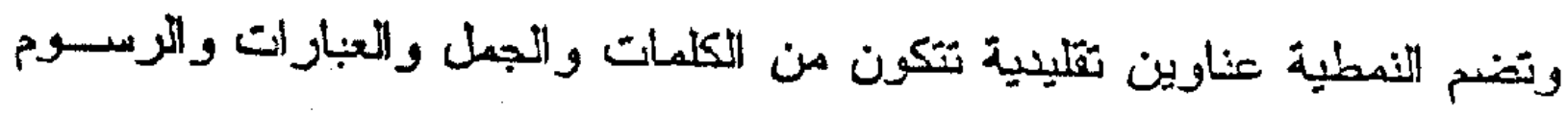

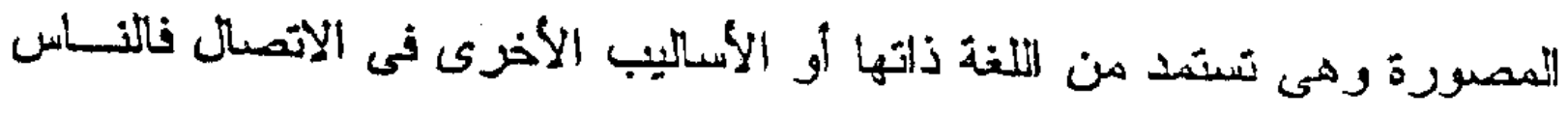
غالبا لا يرون الأشياء والحقائق قبل تحليدها ولكنهم يحنسونها ثم يرونها بالكيفية

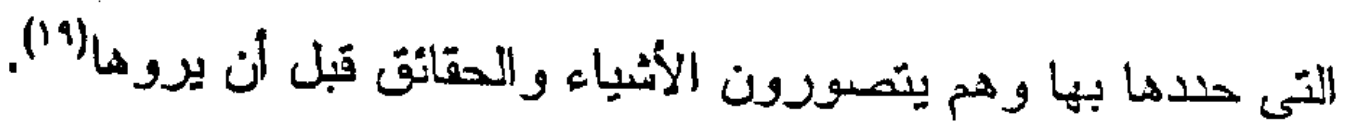




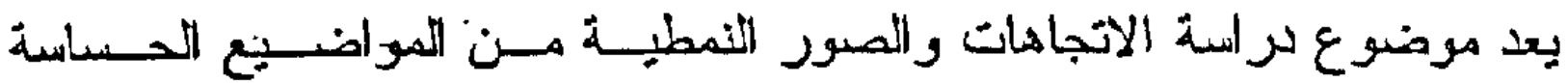
والثُائكة التى خشي كثير من الباحثنين العرب من دراساتها أو الخــوض فيهـا وعلى اللزغم من التوسع الغربي فى دراسة وانتشار مفهوم الصور اللمطية فـى المدول العربية وأهميتها فى رسم سياسة تلك الثول إلا أن الدول العربية لم ترك أهميتهبا بعد على الرغم هن أن العالم العربي في حاجة ملحة لتحسبين صــورته المنطبعة لدى الكثير من شعوب العالم تلك الصورذ التى شودت من قبل أعسداء الأم العربية بإمكانياتهم واجهزتهم الإعلامية الضخمة ما زلال هـؤلاء الأكسداء

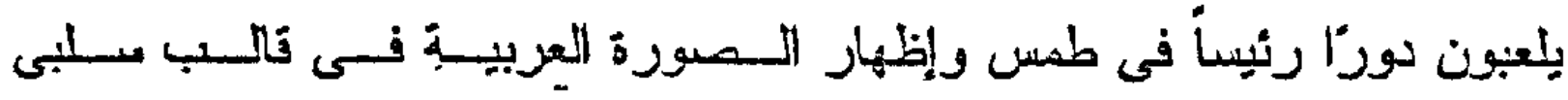
وسى (r.) (r)

ويؤكد بطرس غالى أن وسائل الإعلام الغربية عموما تميل إلى إعطاء صسورة

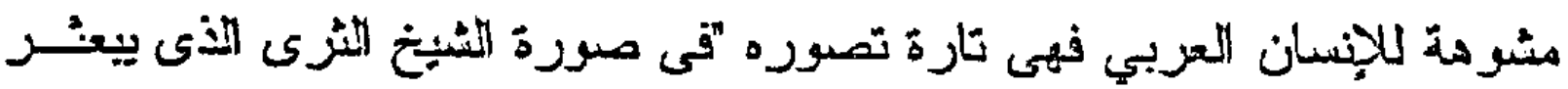
أمو الند بإيسراف فى النوادى الليلية وعلى هوائد التقار وتارة تمبوره فى صسورة

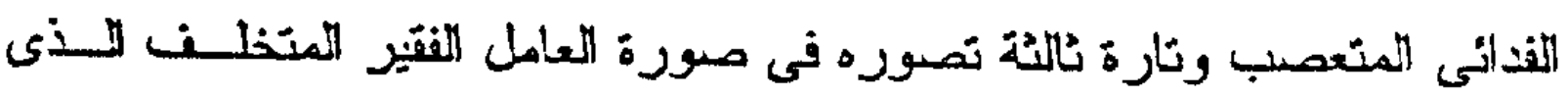

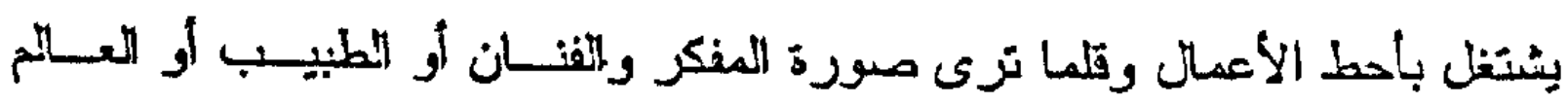

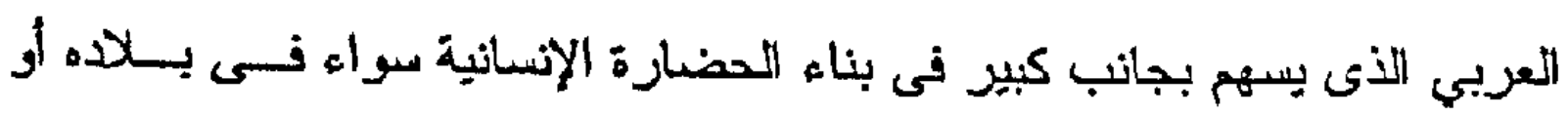
خارج بلاده فى المعامل والجامعات النتى ينخر بها العالم المنقتم"(ri).

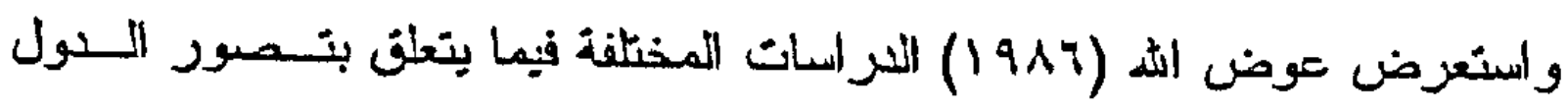

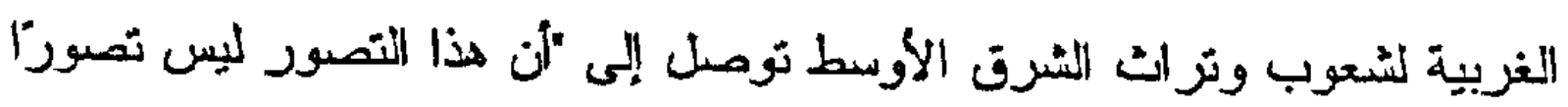


مثكاملاً بل يقوم على متنطفات هجزأة نتسم بلاتحيز وعنم الوعي حثى فى مجلال

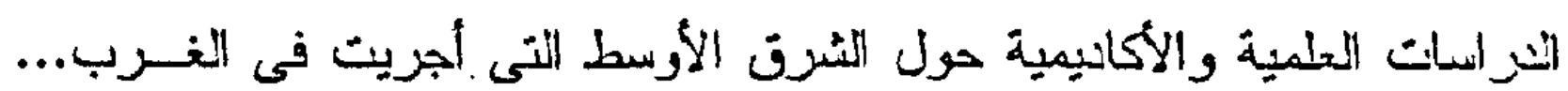
ولئا فليس بغريب أن ينظل النزبي إنى العرب على انهم مجرد مصلر للـنفط

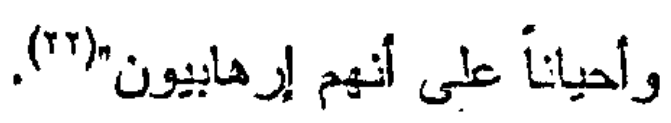

وتكونت مبور الحزب عند الثعب الأمريكي عن طريق وسائل الإعلام الأمريكية نتيجة لعوامل عنيدة دنها الصراع العربي الإنرائيلى، مصلاح الولايات المتحدة

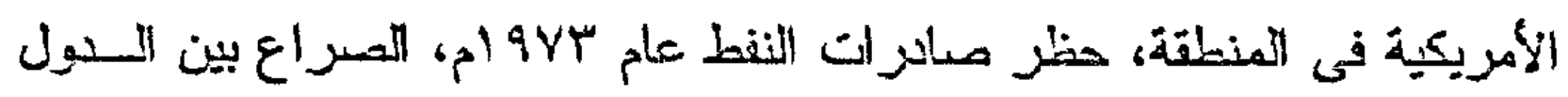

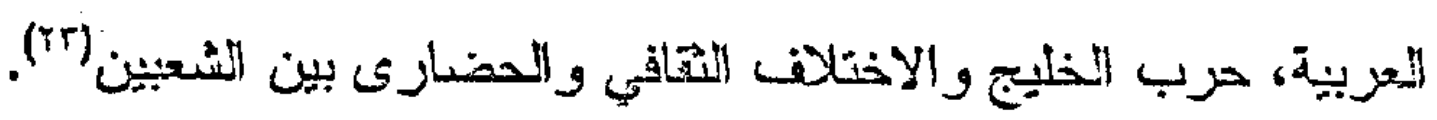

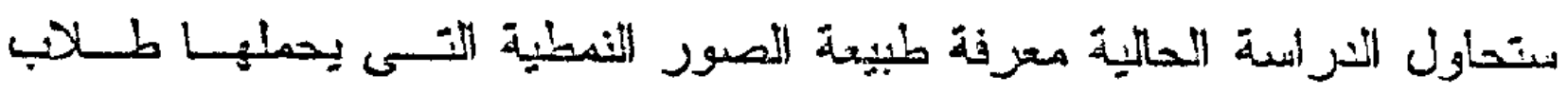
الجامعات الأمزيكية في أنهانهم تجاه المعزب ربخاصة فى عصر التعولمة الحالي والانقلانب في موازين القوى اللولية وظهور اللنظام العالمي الجنيد الذي تتزعما

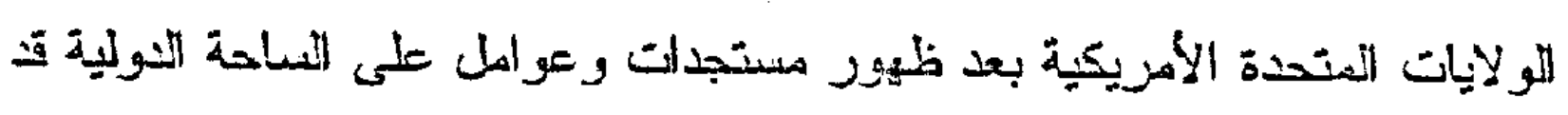

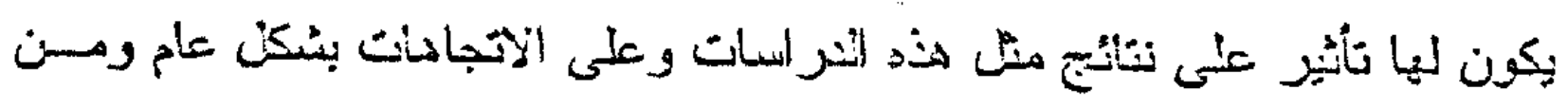
هذد الكوادل:

1- اتفاتيات أوسلو بين الفلسطينيين والإسر الثليين وما أعتبا من مسرؤتمرات

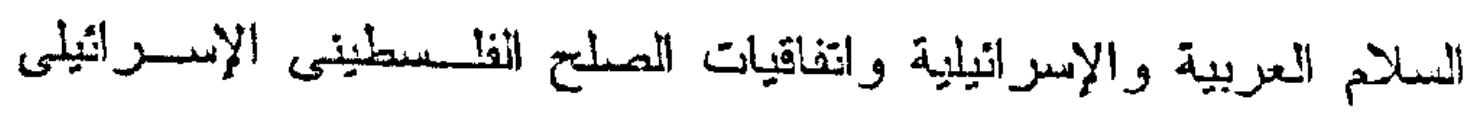
والأردني الإسر الثيلى.

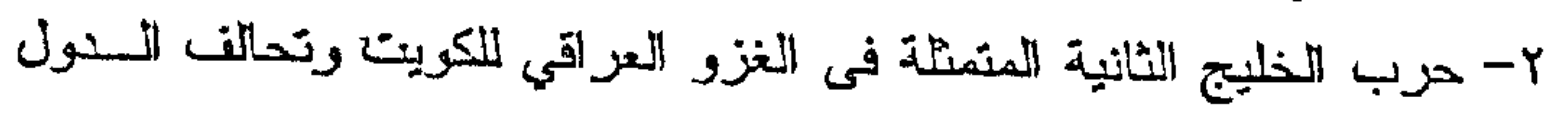
العربية والإنلامية والنغبية لتحرير الكويت من التوات العراقية الغازية. 
ب- تخفيف حدة الهجوم الإعلامي على إير ائيل وتصريحات بعض السسباسة

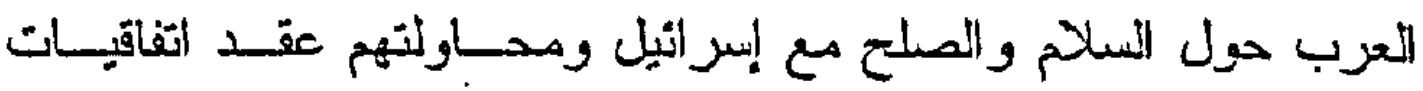

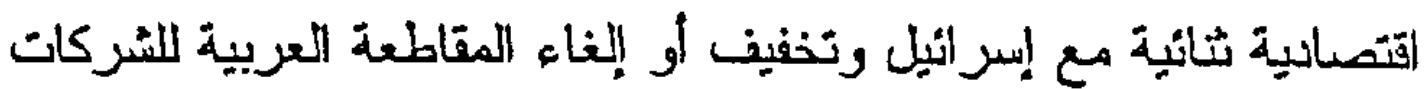

$$
\text { التى تثعاهل مع إبر ائيل. }
$$

ع- تضمين الخطاب السياسي الموجه إلى الشارعين العربـي والإســرائيلى

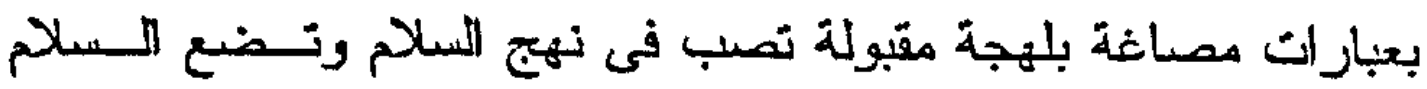
ضن أولويات الحكومات العربية وإبرائيل.

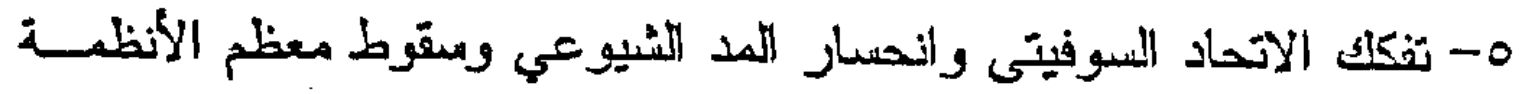

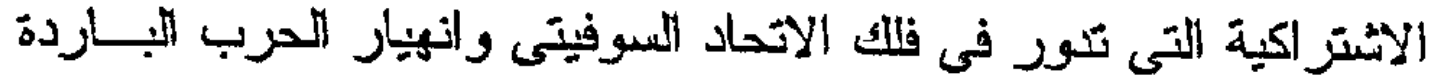
وهيمنة الولايات المتحدة الأمريكية على تزعم العالم. لقد مظيت أبحاث الاتجاهات والصور النمطية بانتمام كيير من الباحشين الغربيين وأجريت اككير من المراسات المكنفة وخاصة فى الولايات المتحـدة الأمريكيـة والتى كانت فى معظهها تكور حول السمات المخصية لأفزاد المجنمع الأمريكي

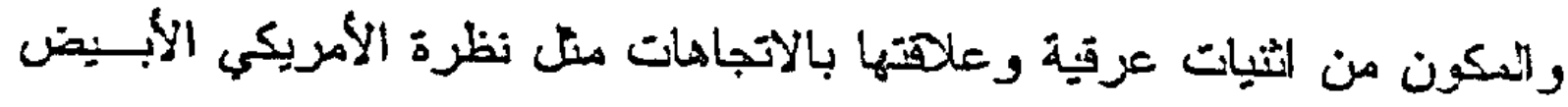
للأسود ونظرته للأمريكي من أصنول مكسيكية أو يابانية (كاتز بهو ا، برلهـى ونى (rí)( 19 (190 غ وقد أجريت عدة أبحاث حول اتجاهات الشعوب تجّاه بعضها الآخر نسى بعسض

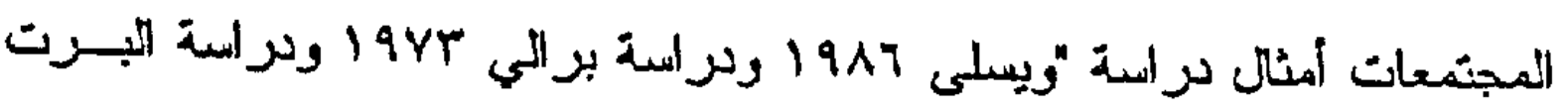
$($ (ro) $)$ (9ג.

ولا ثثك أن هذه التعميمات والاتجاهات السلبية لها أثكر كبير فى خلت العداء بين

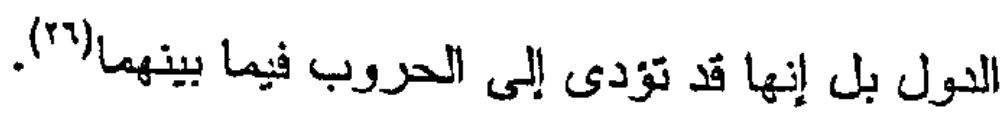


ويلخص بولننج نلبـ بتوله ".... لمن الاهنمام بموضوع الصور الذهنية قد تزايسد

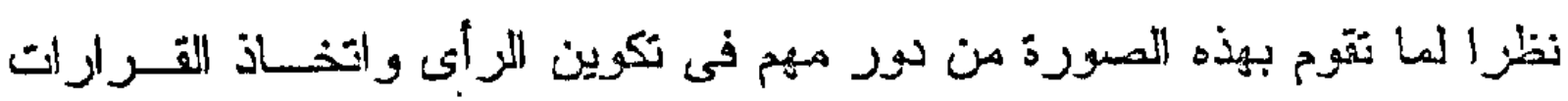
ونتكيل السلوك "ويؤكد بولننج أن الكيقية التى يتهرن بها الإنسان تعتمد على الصور الأهنية التى يحملها تجاه الغير وأن أي تغيير بصيب السصورة بسستبع

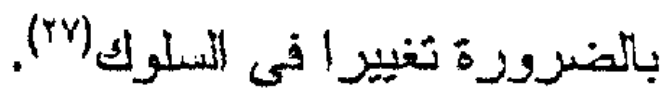

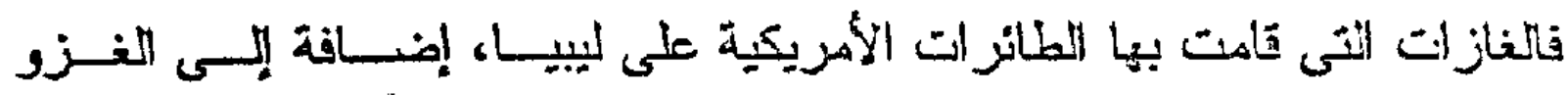

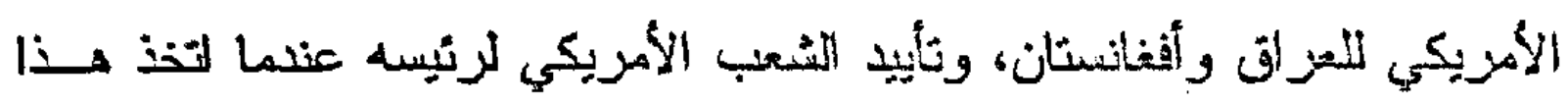

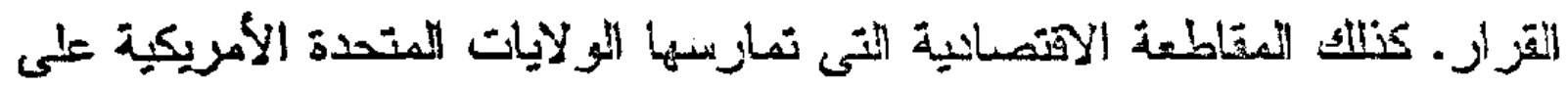
بعضن الإىل بمباركة ومشاركة من جميع الثول الأخرى في الأمم المتحدة والنى

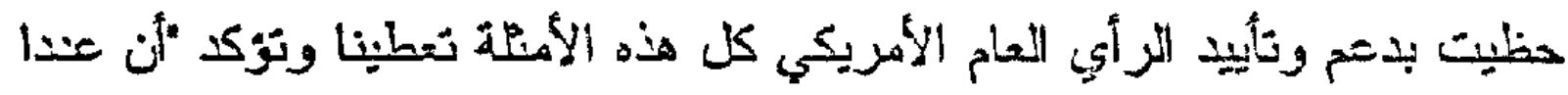

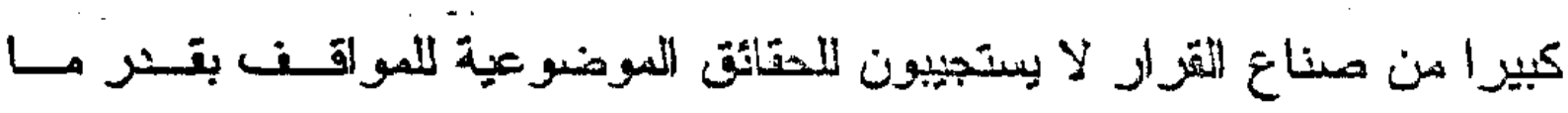

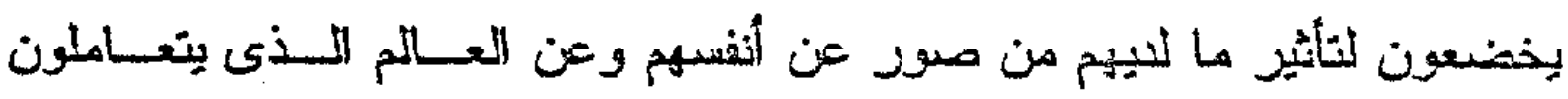

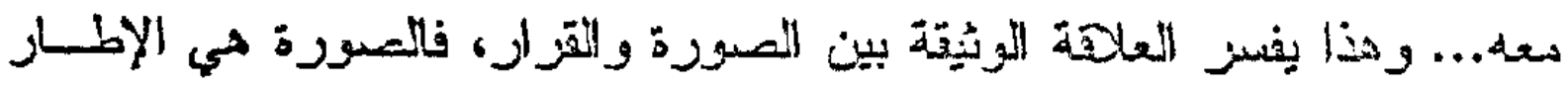

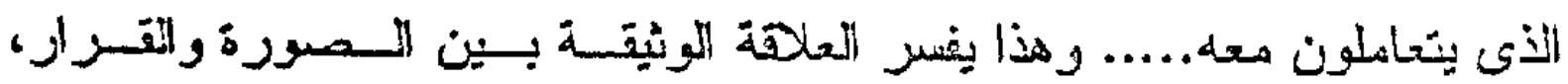
فالصورة هى الإطار الإنسى العام لاتخاذ القزارات وهي البيئة النفسية للتى يستّ

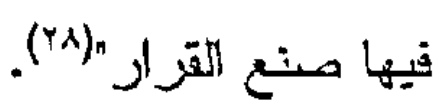

ومها يزيد فى أهمية اللراسة الحالية الثور الكبيز الذى تؤيه الولايات المتحـدة

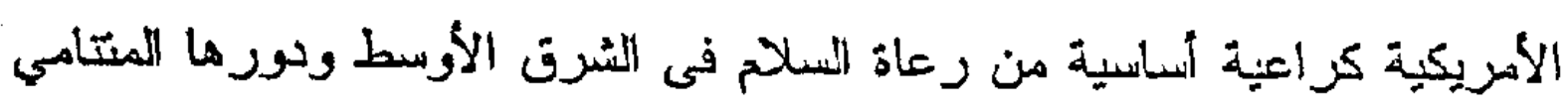

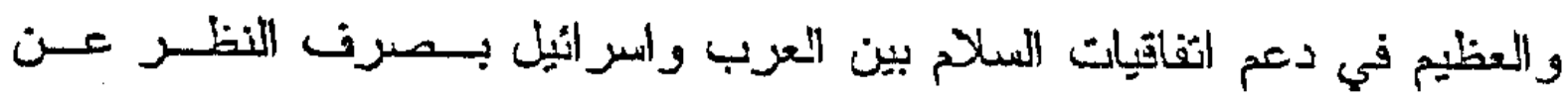

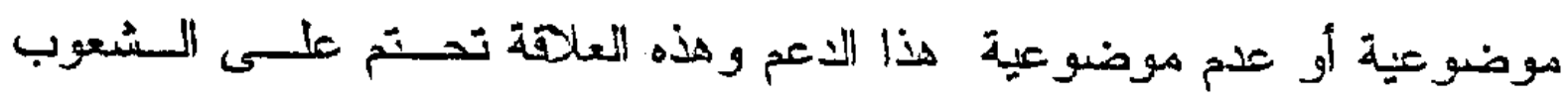


المزبية و الثشعب الأمريكي أن يفهم كل منيها الآخر وأن يعرن كل طــرف مــا بلور فى ذهن الطرف الآخز تجاه بعضوم البعض هن مفاهيم ومعثقات وصور ذهنية حتى يتم تصديح المفاهيم الخاطنة وبنعيم الاتجاهات الايجابية والــتخلص من الايجابية والتخلص من الاتجاهات والصور السلبية.

فالاتجاهات السلبية على وجه التحميد كأحد شكلي الاتجاهـات بـين الجماءـات (إيجابي وسلبى) لها. قمر كبيز من الأهمية لما يترثب عليها من آثار سلبية على جوانب عنيدة تشعل المنواهي الاجنماعية والاقتصالية والسمسياسية فـى سـائر المجتصعات الإنسانية وتتعكس هذه الآنّار السلبية على هذه المجتمعات فى عمومها

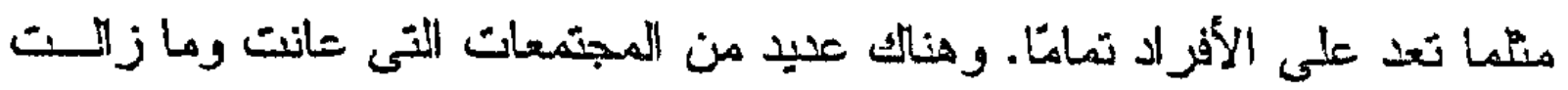
تعانى هن تلك وغيز ثايرة على مواجهية هذه المشكلة(r9).

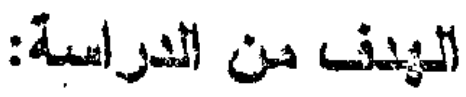

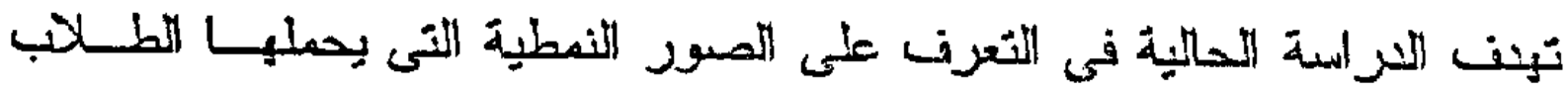
الأسريكيون الملتحقون بجاهعة (UCLA) ذى الفصل الصنيفي لعام . .. Yم تجبـاه العرب والكثّف عن مدى الاختلاف في هذه الاتجاهات باختلات الجنس والعزت والمستوى اللراسي، كما تهن هذه المراسة إلى التنعرث على مصاير المعلومات النتى استقى منها أفراد العينة معلوماتهم عن العرب. أسئلة المر (سية:

تستوف اللراسة الحالية الإجابة على الأسئلة التالية: 
ا- ها هيى الصعور الذهنية التى يحدلها طلاب جامعة (UCLA) تجاه العرب؟? ب- ها همى الصور اللذهنية التى يحملها الطلنب والطبلبات تجاه العرب، وهل توجد فروق ذات دلالة احصائية بيذهم فيما بتعلــن باتجاهــاتهم ندسـو

$$
\text { المعرب؟ }
$$

r- ها هي الصور الذهنية التى يحملها المطلاب البيض والمسود تجاه العسرب وهل توجد فروق ذانت دلالة إحصائية بينهم فيما ينعلت باتجاهاتهم نحسبو

$$
\text { الإعزبـ. }
$$

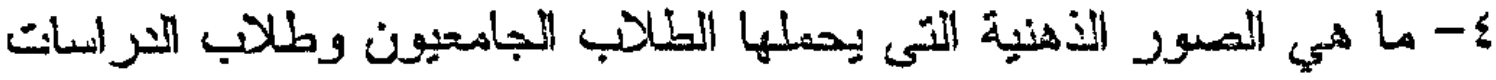
التعليا تجاه العرب وهل توجد فروق ذايت دلالة إحصائنية بينهم فيما يتعلت

$$
\text { باتجاهاتهم نحو العزبب؟ }
$$

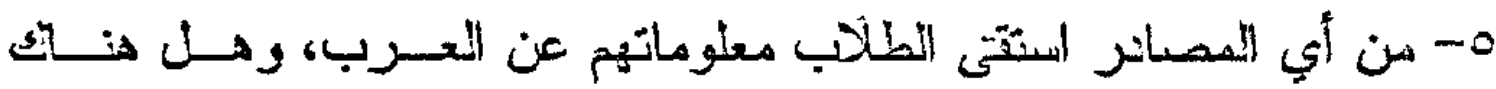
نزوت دالنة إحصـائيًا بين مصدر المعلومة والاتجباه نحو التعرب؟

\section{:}

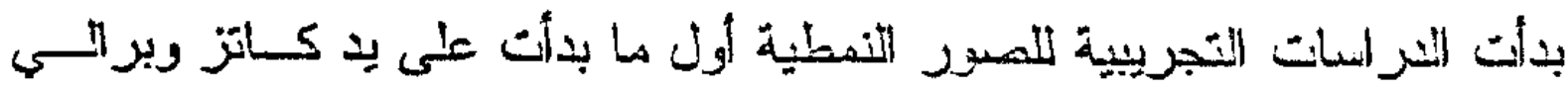
Katz and Braly

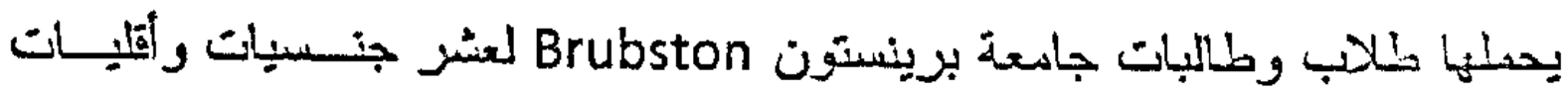

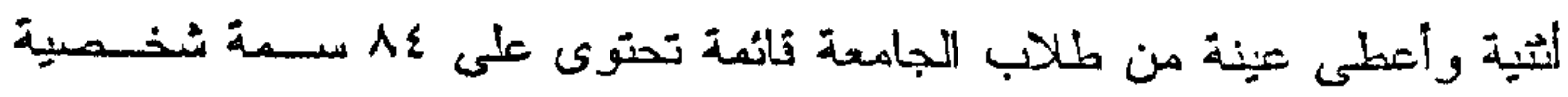
وملب منوم اختيار م صفات من التانعدة يعتقون أنها تتطبن وتصن الجنسيات والأمليات العشر التالية: الألمان، الانجليز، اليهود، الزنوج، الأيز الك، اليابـانيين، الأهريكيني، الإيرلنيين، الصينين. 


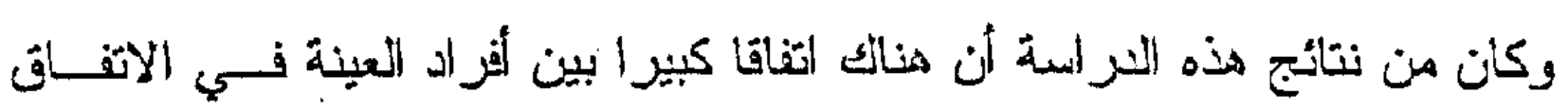
على اختيار الكلمات التّى تصف هذه الجماعات فمئلا هو\% من أفــراد العينــة وصفوا الزنوج بأنهم كسالى و و \% وصفوا الليهود بـانهم عنيفـون، و الألمـان

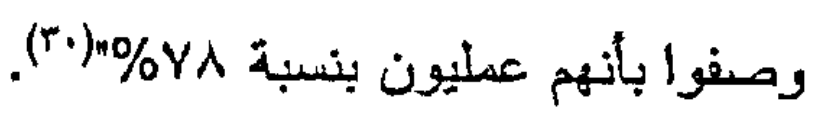

واستعرض عبد الله (919 1) نتائج بعض الدراســات التـى الجريسـت لقيـاس الاتجاهات نحو القوميات المختلفة التى توصلت إلى وجود تفسضيلات مستوعسة لأبناء التقوميات المختفة تجاه بعضهم البعض على أساس الصور النمطية التـي لئي تكنبا كل قومية عن الأخرى (الألمان، اليابانيين، الزوس... إلخ) وأكثر القرميات الآى ينفز منيا الأمريكيين هي القوميات الشرقية منل الصبينيين واليابانيين... إلخ بينما أكزر القوميات التى يفضلونها هى القوميات الأوروبية الغربية(Iا") وقام سينيا وإيداهي Sinha and Upadhyay سنة (197) بإجراء مراسة على

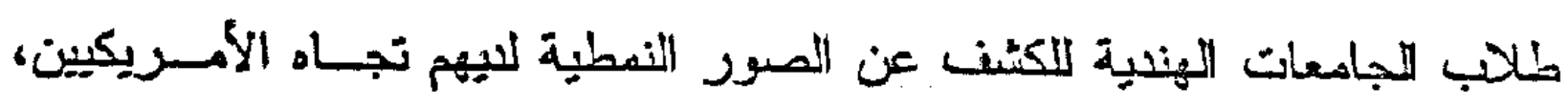
الصينيين، الانجليز، الفرنسيين، الأمان، الــروس، الززنسوج والباكستئنيين.... وكانت نتيجة هذا الدراسة أن أفراد العينة وصفوا الباكستانيين والززنوج بـصفات سلبية ووصفرا بقية الجنسيات الأخرى بصفات الِجابية، فالززنوج وصفوا بـأنهه مغفلون، منخلفون، منحطون، بينما الباكستانيين ومسفوا بأنهم وحشيون وأنانيون

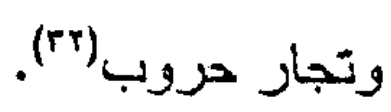

وقاما كاتز وبر الي Katz and Braly سنة (1904) ويوى وهومبر Dewey and Humber 
المدارس الثنانوية فى أمريكا عن ست جنسيات مختلة وجاعت نتائج هذه المراسة على الندو المتالى:

$$
\text { • الألمان (مجتهون - أنكياء - عمليون - عدوانيون). }
$$

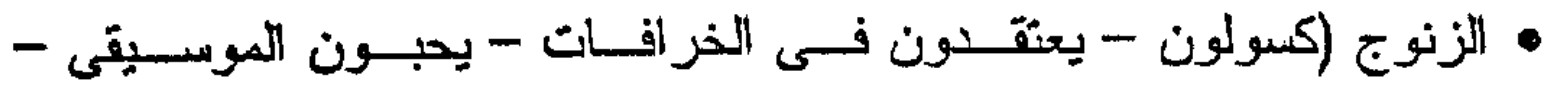

$$
\text { ثنهوانيون). }
$$

$$
\begin{aligned}
& \text { ه الإيطاليون (حادو الطبع - ثزئارون - مرحون - متلينون) } \\
& \text { • اليهود (مكارون - مجنجونون - طماعون - مانيون). }
\end{aligned}
$$

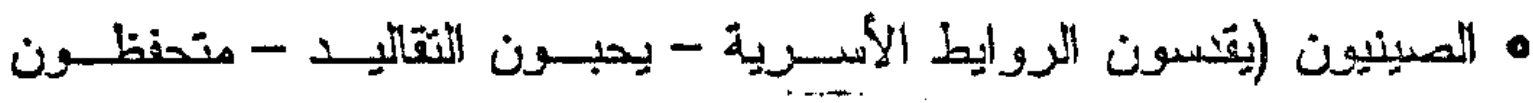

$$
\text { هانئون) (كT) }
$$

وقد أكلت اللمراساث أن الصور النمطيتمكتبة لأننا لانولد وفى أذهاننا صسروز

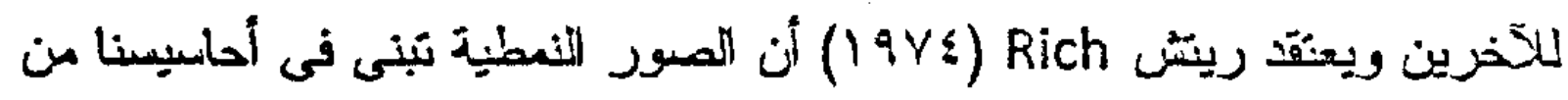

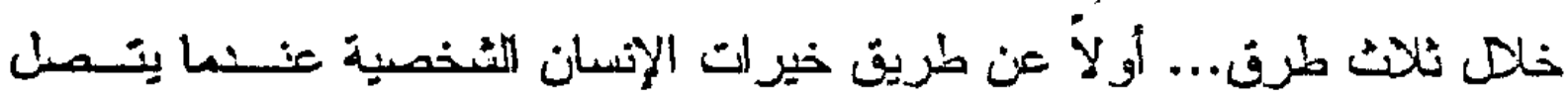

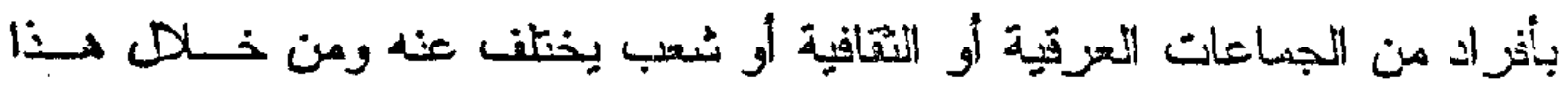
الاتهـسل يبدأ الشخص بتعميم بعض السمات أو الصفات السلبية و الإيجابية 'على

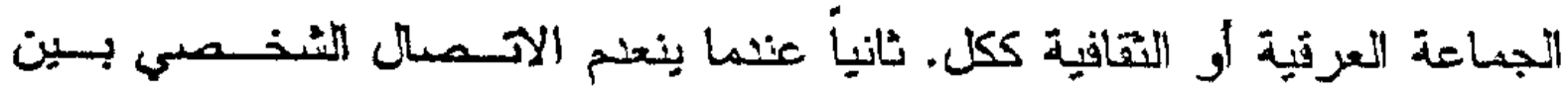

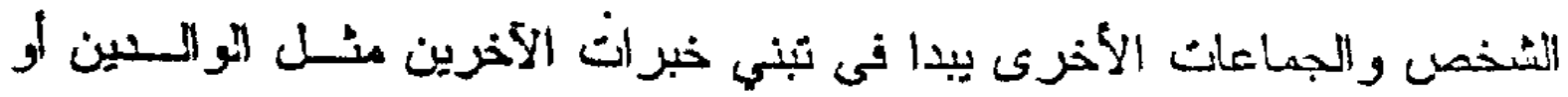
العسربة أو زملائه أو أمسقائه (الجماعات المرجعية) في تشكيل المبور النمطية عن الناس أو الأنشياء. يبنى الإنسان صورة النمطية من خلال ما تقمه له وسائل الإعلام مل الكتب، المجلات، الصحف، الراديو، العينما، التلفزيون عن الشعوب

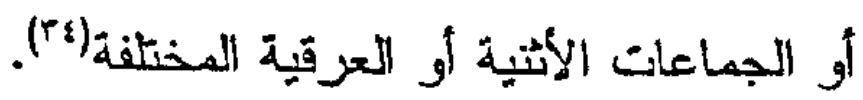


ربالزرثم من الثور الكبيز الذّى تؤنيه وسائل الإعلام في تكوين وستكيل الـمبور

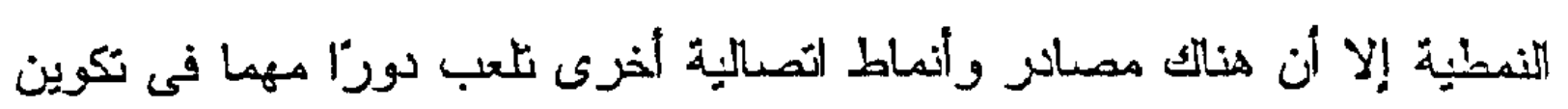

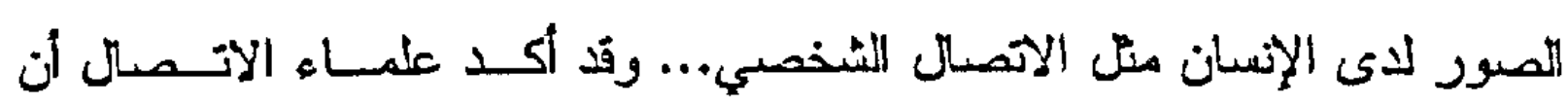

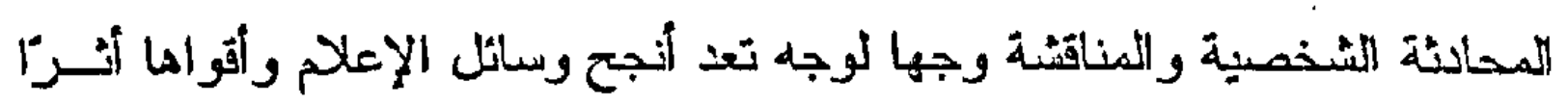

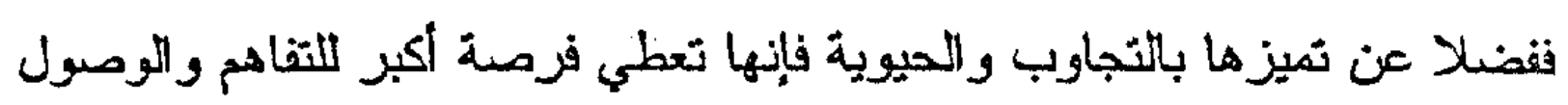
إلى نتائج ملموسة (ro).

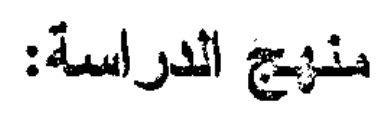

هينتيع اللدراسة: تعد الجامعات من أهم المعاقل التـى تــــ الإدارة الأمريكيسة بالو نائف العامة والقيادية ولطلاتب الجامعات الثور الكبير والهام فى بلوردَ وخلت

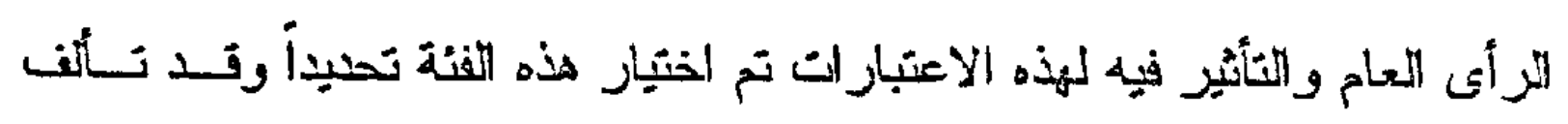
مجنسع هذه الدراسة هن طلانب وطالبات جامعة كاليفورنيا فى لــوس أنجلـوس

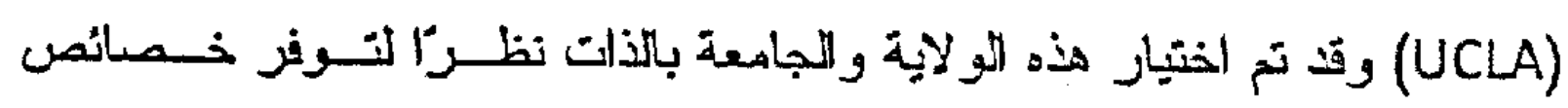

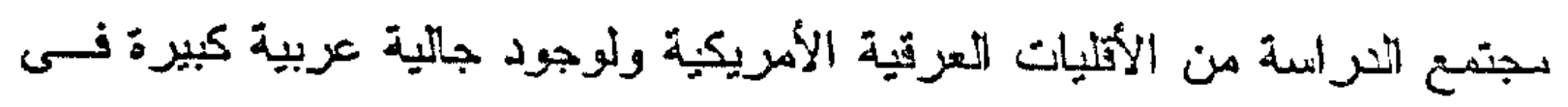
هذه الولاية.

عينة اللراسة: تكونت العينة التى اعتمدت عليها مذه المراسة مسن •ب؛ مسن اللطلابب الملتحقين بجامعة كاليفورنيا لوس أنجلوس (UCLA) فى الفمل النراسي الني

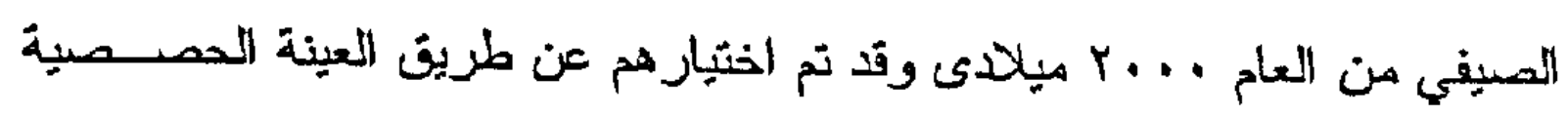

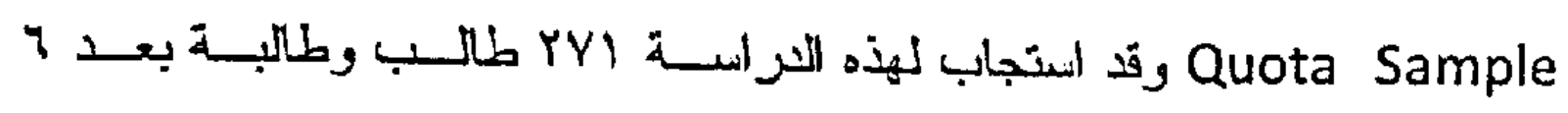

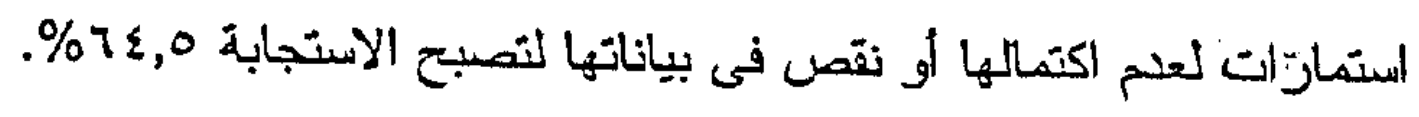




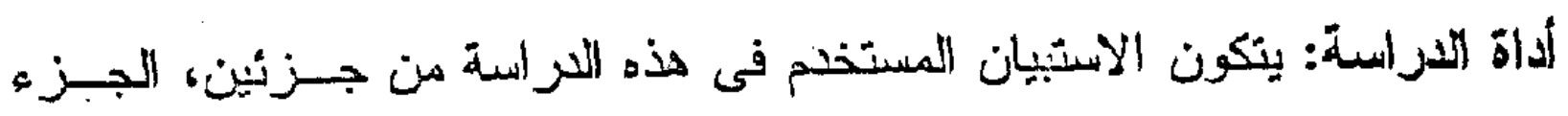

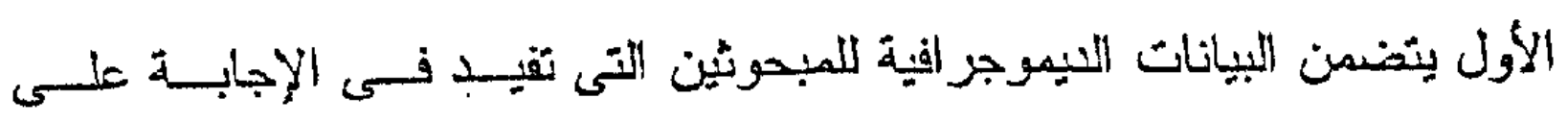

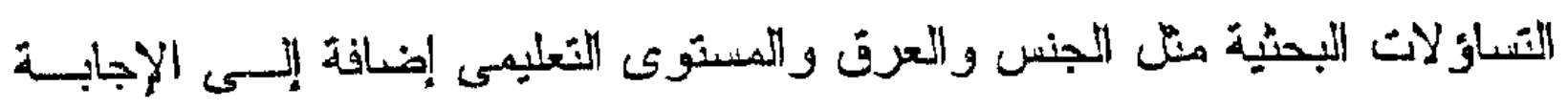

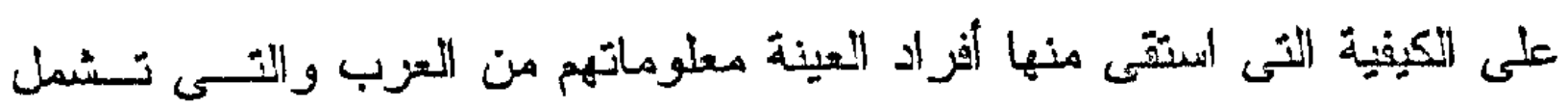
الصحافة أو التليفزيون أو المجلات أو الاتصال المخصنى.

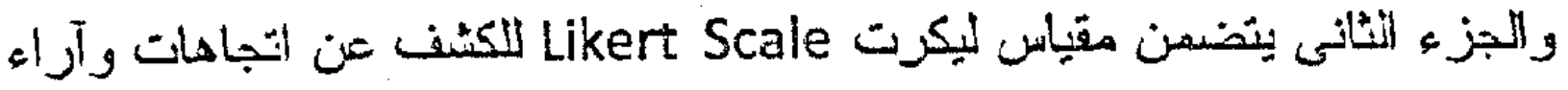

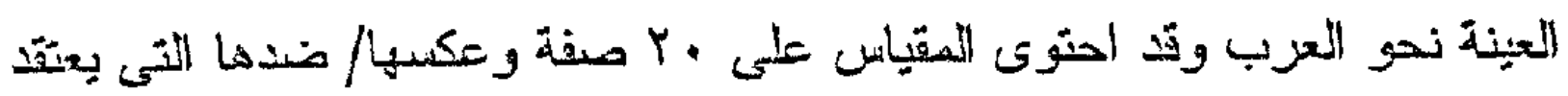

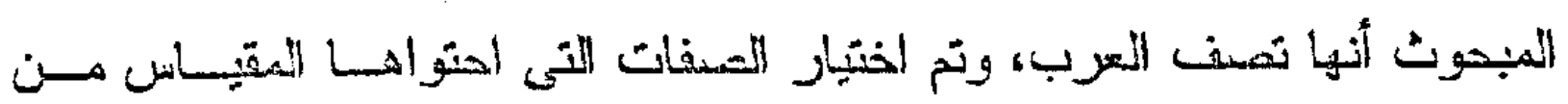

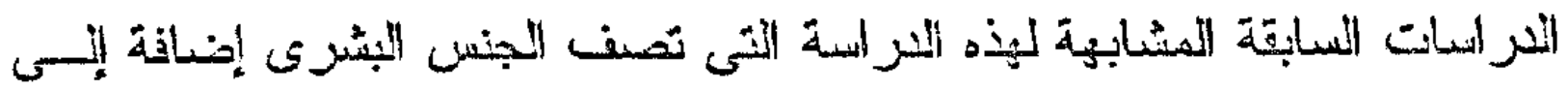

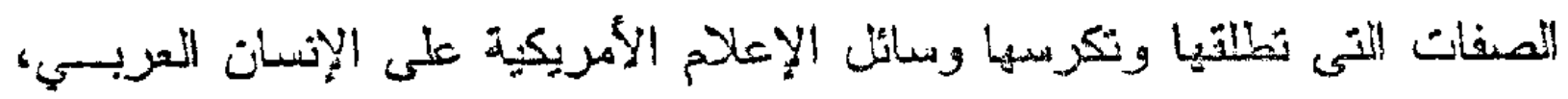

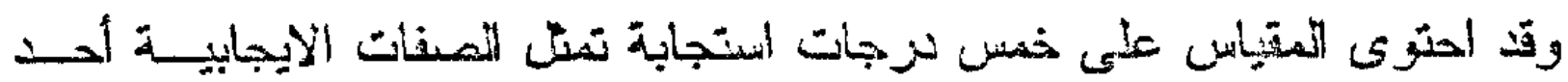

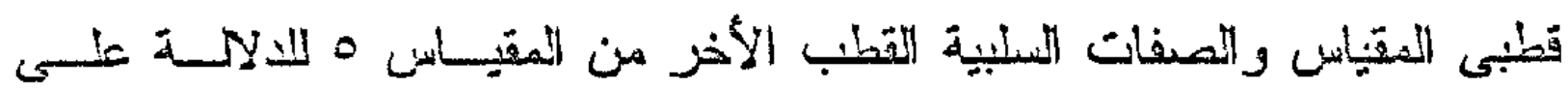

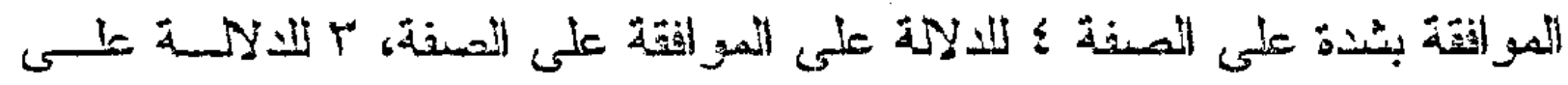

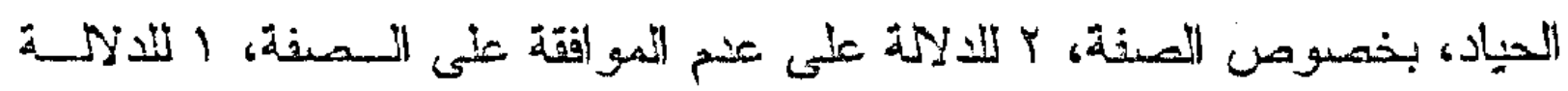

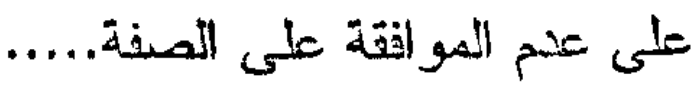
المعالجة الإحصدئية تمبت المعالجة الإحصنائية للار اسدة كما بلى

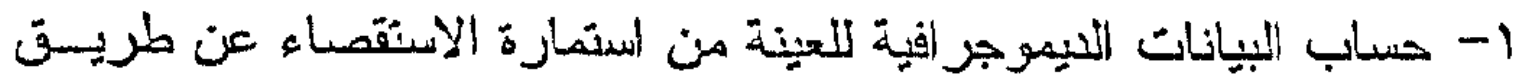
النكر ار الت و النسنب المثيّوية. r- تحليد الهـورة الذهنية التىى يحملها أقراد العينة تجاه العرب عن طريق

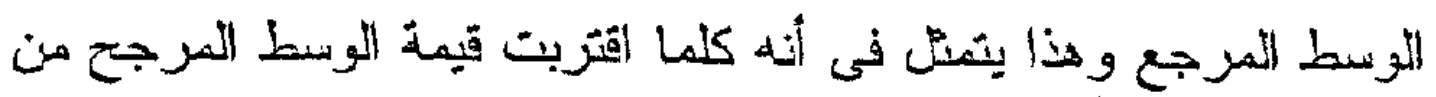




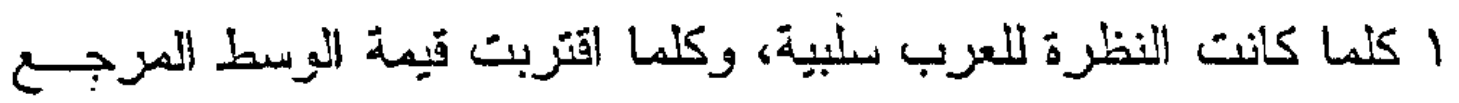
أقلّ من ويالقرب من r كلما كان اتيجاه الآراء الحياد السلبي..... وكلمــا

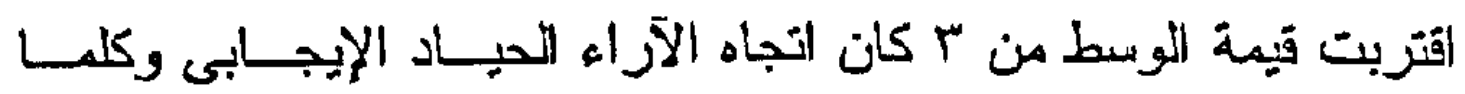
اقتزبت قيمة الوسط المرجع من ه كان اتجاه الأراء ايجابي. ب- تم حساب المقارنة بين استجابات أفراد المعينة حسب الجـنس والعــرت والمستوى التحليمي عن طريق الوسط المرجع، كما ثم حساب الفـروت

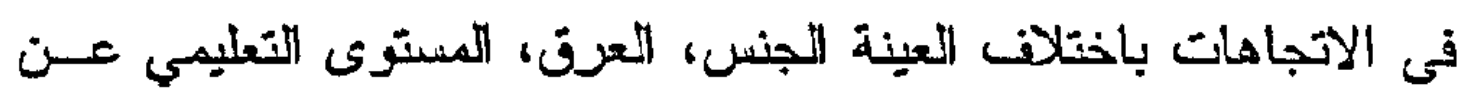

$$
\text { طريق استخذام اختبار "ت". }
$$

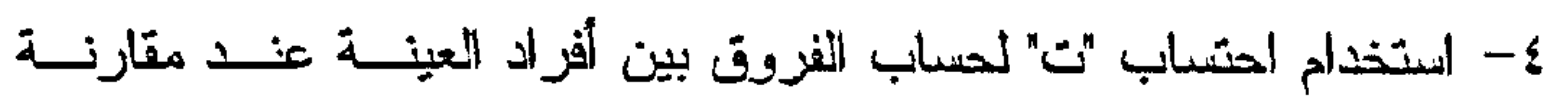
المصاير التىى السنقى منها المبحوتين معرفتهم عن العرب.

(f)

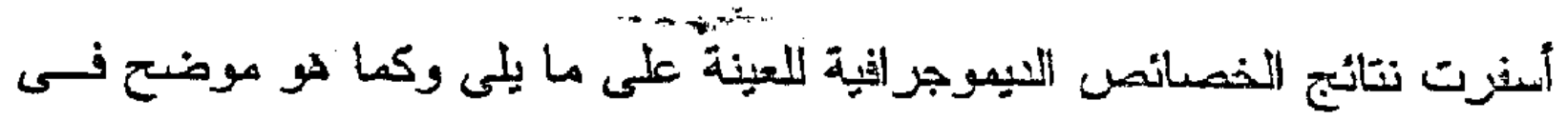
(1) النجول رقم

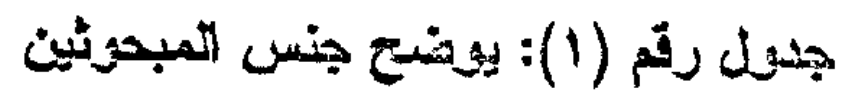

\begin{tabular}{|c|c|c|}
\hline المنسبة & النتكزار & المنس \\
\hline$\% 00,7$ & 10. & $\$ b$ \\
\hline$\% \leq \varepsilon, \varepsilon$ & $|Y|$ & إلطاتبات \\
\hline$\% 1 .$. & YVI & : المجمور ع \\
\hline
\end{tabular}


يوضت جلول (Y) العرق الذى ينحنر منه المبدوثين والذي يشير إلى أن الفالمبية العظمي من أفزراد المينة بينحرون من أهسول انجلوسكسونية من البيض بنسسبة

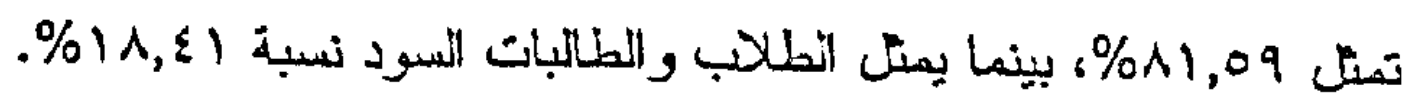

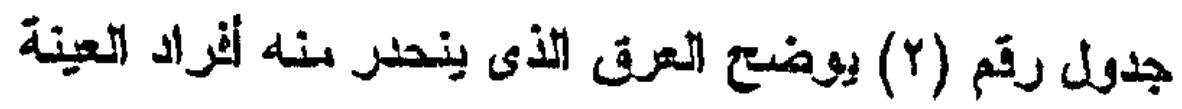

\begin{tabular}{|c|c|c|}
\hline التنسبة & التكراد & (3) \\
\hline$\% \wedge 1,09$ & YY. & آبيضض \\
\hline$\% \backslash A, \leqslant \mid$ & 01 & \\
\hline$\% 1 \ldots$ & YVI & \\
\hline
\end{tabular}

وتنير نتائج الجحول (T) الذي يوضح المستوى التمليمي للمبحوثين أن أكثر من

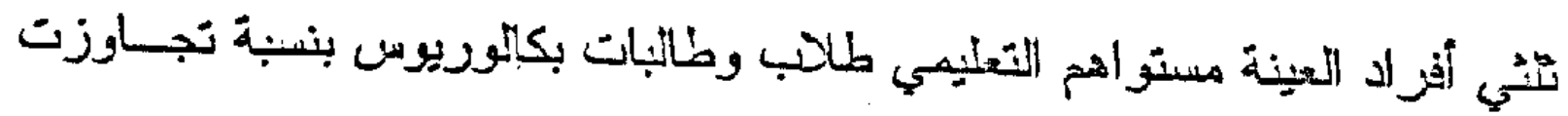

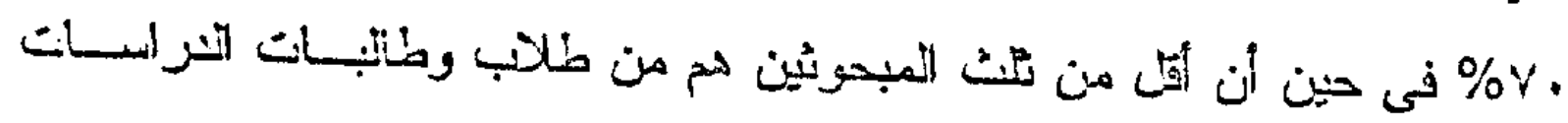

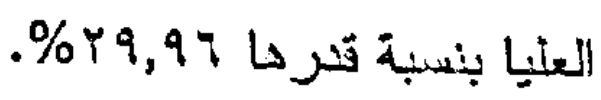




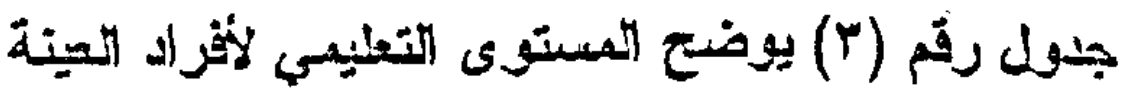

\begin{tabular}{|c|c|c|}
\hline التنبية & التيكرار & المستوى التطبيمي \\
\hline$\% v \cdot, \cdot \varepsilon$ & 19. & | جامعى \\
\hline$\% r 9,97$ & AI & لر است عليا \\
\hline$\% 1 \ldots$ & YYI & 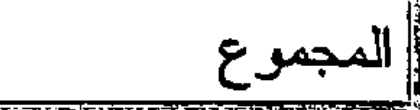 \\
\hline
\end{tabular}

تبين نتائج الجلول (\&) مصادر المعلومات التى اســتقى منهــا أفــراد العينــة

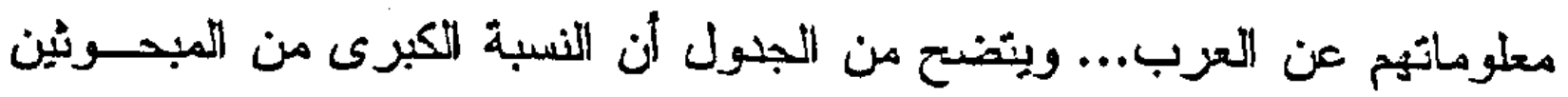

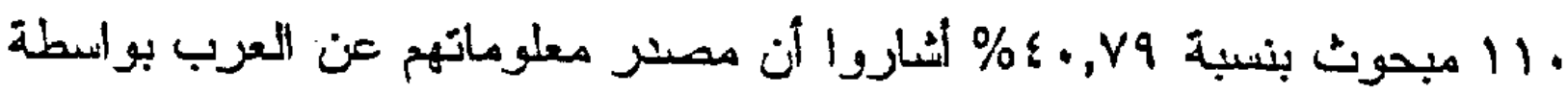

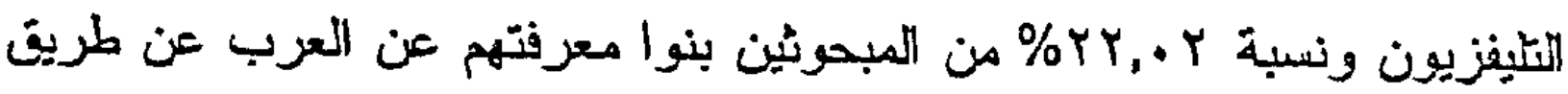

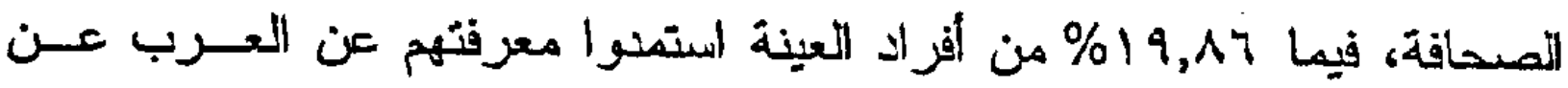

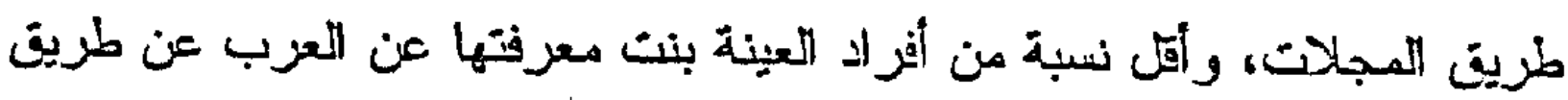

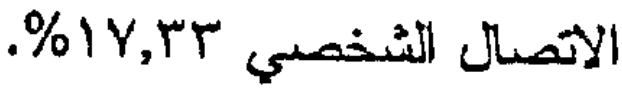
جنول رقم (2) يوضح مصادر المعلومات الئى لستخمها المبحوئين معرفتهم عن

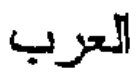

\begin{tabular}{|c|c|c|}
\hline النسبة & التكرار & العصلر \\
\hline$\% \leq \cdot, \vee q$ & 11. & التليفزيون \\
\hline$\% Y Y, \cdot Y$ & 7. & الصحافة \\
\hline$\% 19, \wedge 7$ & $0 \leqslant$ & المجلات \\
\hline$\%$ IV,rr & $\varepsilon V$ & الاتصلال الشخصىى \\
\hline$\% 1 \ldots$ & YVI & c \\
\hline
\end{tabular}


طزح البحث مجمويتة من الأسئلة ولملإجابة على السؤال الأول المتعلق بماهبيسة

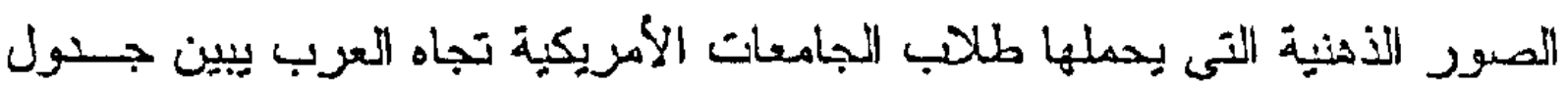

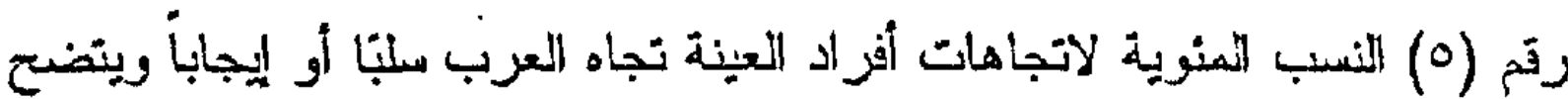

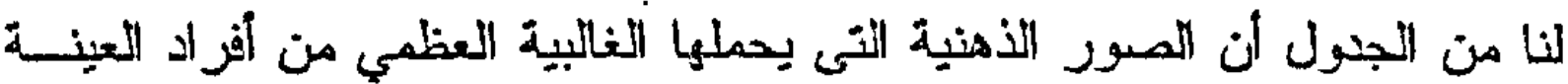
تجاه العزب هي محايدة.

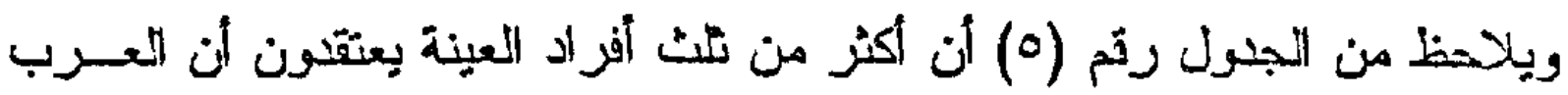

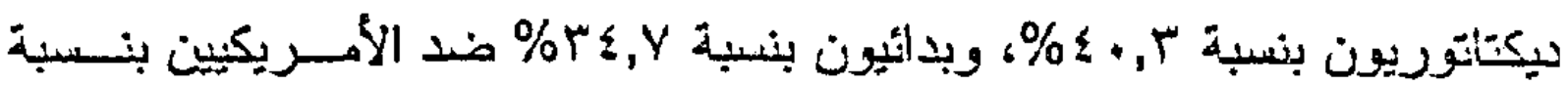

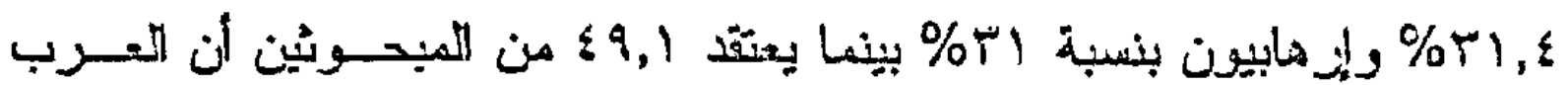

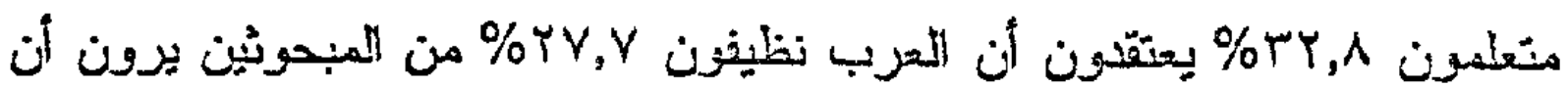

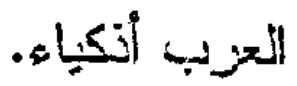

\section{(0) جلول رقتم}

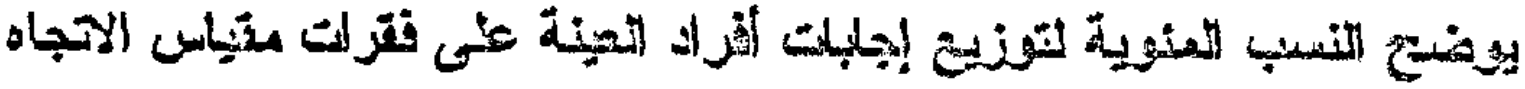

\begin{tabular}{|c|c|c|c|c|c|}
\hline \multicolumn{2}{|c|}{ } & \multicolumn{2}{|c|}{ الإجهات الزيجلية } & \multirow{2}{*}{\multicolumn{2}{|c|}{ 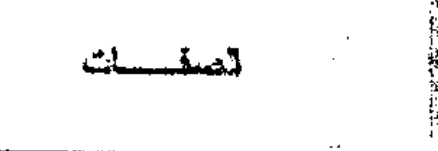 }} \\
\hline تحسبة & ليطد & التمسية & In: & & \\
\hline$\% 1, Y$ & Yo & $\% 1 \cdot, r$ & YA & تغيز أفين & أمين أمين \\
\hline$\% \backslash\{, \lambda$ & 4 & $\% r \varepsilon$, & 10 & لديث: & 倠 \\
\hline$\% 6 \mathrm{Y}, \mathrm{Y}$ & $Y$ & $\% 19,9$ & e \{ & سم:" & ج \\
\hline$\% \varepsilon \cdot, r$ & 1.1 & $\% 1, r$ & Yo & ديكثاتور & 1) بيستراطن \\
\hline$\% 10.1$ & $(1$ & $\%$ YY,Y & ro & تغبى & 5 \\
\hline$\% i r, r$ & $r$ & $\% \backslash \varepsilon, 1$ & $\varepsilon$. & جبن & أشباع \\
\hline$\% 1 \cdot . r$ & $r \wedge$ & $\% т, r$ & IY & : كلم & $\omega=$ \\
\hline$\% 4,7$ & 11 & $\% \leq r, 1$ & 111 & نقير & | \\
\hline$\%$ \%.. & $\wedge \xi$ & $\% 0, Y$ & 18 & إلرهانبي & 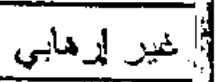 \\
\hline$\% \backslash 7, Y$ & $\varepsilon \varepsilon$ & $\% \wedge, 1$ & YY & تابع & ل1 \\
\hline$\% \wedge, q$ & $Y \varepsilon$ & $\% Y), 8$ & ON & هنيفت & تمي تمي \\
\hline$\% \wedge, q$ & $\leqslant Y$ & $\%$ \%ч, & 78 & فج & لطبن \\
\hline$\%$ \% & $9 \varepsilon$ & $\% 1 \cdot, r$ & TA & بدانتى & | متحفر \\
\hline
\end{tabular}




\begin{tabular}{|c|c|c|c|c|c|}
\hline \multicolumn{2}{|c|}{ الإجها لتصلبين } & \multicolumn{2}{|c|}{ الاجبلت الإبجلية } & \multirow{2}{*}{\multicolumn{2}{|c|}{ 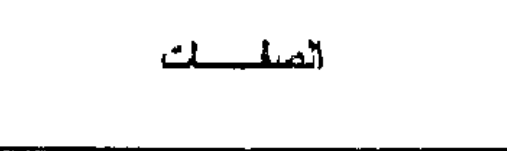 }} \\
\hline لتنسبة & اليعد & للنسبة & البعد & & \\
\hline$\% 1, \wedge$ & 0 & $\%(9,1$ & irr & جاهل & منسم \\
\hline$\% 11,8$ & ri & $\% 14,9$ & ro & غير محبوب & |محبرب \\
\hline$\%$ \%, & As & $\% t, \varepsilon$ & ir & ضند الأمريكينث & مع الأمريكينين \\
\hline$\% r \Lambda_{1} \varepsilon$ & VY & $\% Y, \varepsilon$ & r. & متطرن & |م:متل \\
\hline$\%$ Y $1, Y$ & iv & $\% 1 \leq, \varepsilon$ & rq & كسول & تشيط \\
\hline$\% Y, Y$ & YI & \%ัт,А & 19 & تنز & ) نظينت \\
\hline$\% Y\{, \cdot$ & 70 & $\% \wedge, q$ & $Y \leq$ & مبلع بالمرب & يحب الملام \\
\hline
\end{tabular}

للإجابة على اللسؤ ال النانى والمنعلق بمعرفة الصور الأهنية التي بحملها طلبات وطلانب جامعة (UCLA) نحو العرب وهل هنالك فروق ذات دلالة إحصائية بينهم

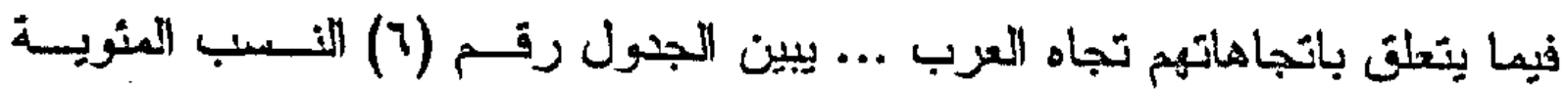

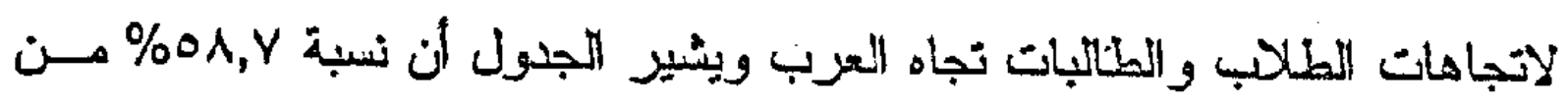

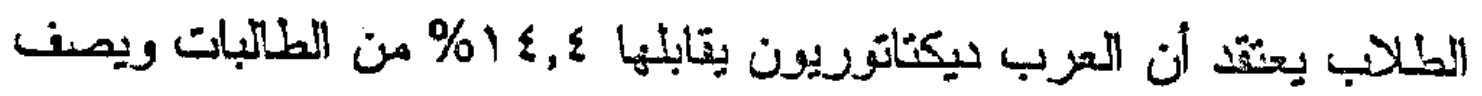

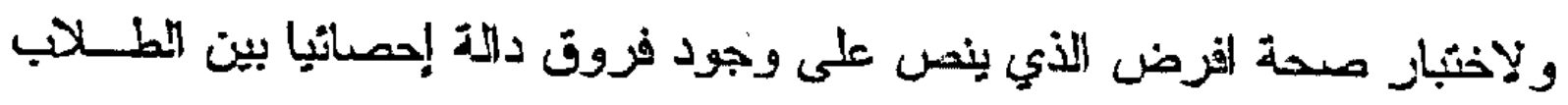

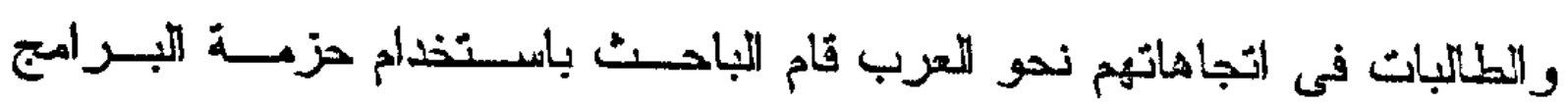
الإحصسائية (SPSS) في حساب قيهة (ت) ويوضدها الجنول رتم (V)

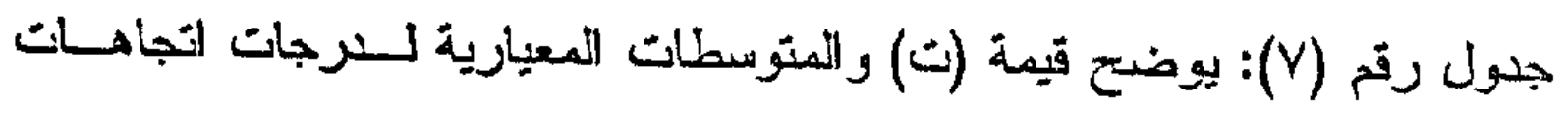
النطلاب وفقا لمتغير الجنس.

\begin{tabular}{|c|c|c|c|c|c|c|}
\hline آلدلة & 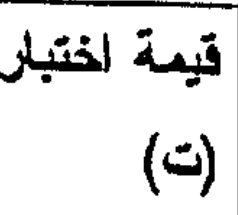 & 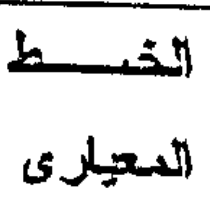 & الالمدرلهـا & المتئوبط & ) & الجنس \\
\hline \multirow[t]{2}{*}{$\bullet, \ldots$} & \multirow[t]{2}{*}{$-\lambda, 10}$. & • • • & -, T & $\Upsilon, \wedge \Upsilon \wedge r$ & 10. & ذكر \\
\hline & & $\bullet, Y \backslash \leq \varepsilon$ & י, YTOAN & $4,179 \leq$ & $|r|$ & انثى \\
\hline
\end{tabular}

*معنوية احصائية عند مسنوى معنوية 0.+. 
ينضح لنا من الجنول رثم (V) ونجود فرق إحصائى معنوى بين اتجاهات النكور والإنات تجاه العزب وهذا يتفق مع قيمني المنوسط المسرجح بالنـسبة للـنكور والإناث حيث اتسمت أر اء الإناث بالحيادية الإيجابية بينما اتسمت آراء الــكور بالحيانية السبلية. وللإجابة على السؤلا النّالث المتعلق بالمور الذهنية التى يحمبا الطلابب البيض

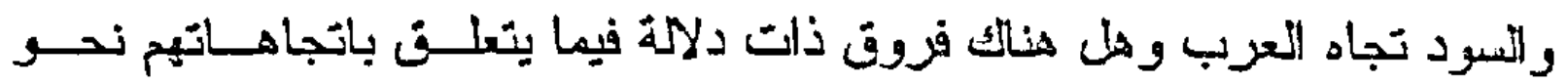
المرب، يوضنح الجنول رقم (ي) النسبب المئوية لاتجاهات الطلادب البيض و اللسود

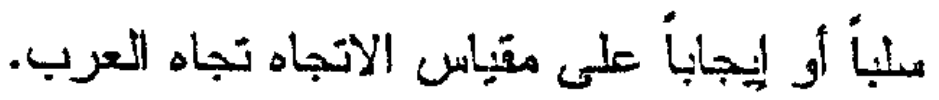

\section{(1) P}

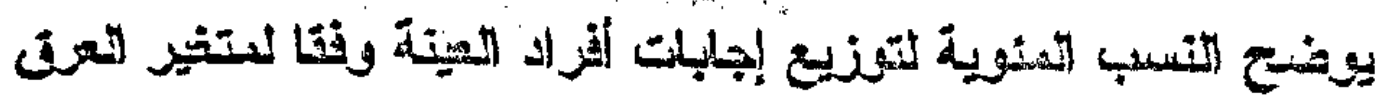

\begin{tabular}{|c|c|c|c|c|c|c|c|c|c|}
\hline \multicolumn{4}{|c|}{ إخجبةت لدسبة: } & \multicolumn{4}{|c|}{ الوجنباث الايجيائي } & \multirow{3}{*}{\multicolumn{2}{|c|}{ النصفــــــات }} \\
\hline \multicolumn{2}{|c|}{ لنب أليضن } & \multicolumn{2}{|c|}{ كعب لمبد } & \multicolumn{2}{|c|}{ بلنه لينض } & \multicolumn{2}{|c|}{ طتبر ألمبدd } & & \\
\hline تمبة & تحيد & تقسبة & لالبد & تصسبرد & لI: & لتعبة & لالمد & & \\
\hline$\% 1 \ldots$ & rY & $\% 0,1$ & 17 & $\% 61 .$. & TY & $\% 1, \lambda$ & rY & ئير المين & المين \\
\hline$g \% 14,1$ & $r \lambda$ & $\% 1 Y, 1$ & $\leqslant \lambda$ & $\%$ YY,Y & Tr & $\%$ \% 9.0 & $\wedge$. & لميم & جميل \\
\hline$\% \gamma, r$ & $Y$. & $\% 9,1$ & YY & $\% \backslash 1, Y$ & $\leq 9$ & $\% Y Y, 0$ & Yo & عب. & t \\
\hline $9 \% 4,1$ & 1.7 & $\% \leqslant 0,1$ & IYY & $\% Y, Y$ & YI & $\% 10, y$ & $2 r$ & ينتّتمدر & بُنيتز أسلي \\
\hline$\% 1 t, 0$ & $r q$ & $\% 1 Y, 1$ & $\varepsilon \wedge$ & $\%$ ro,0 & 79 & $\% r v, r$ & 1.1 & تغبي & نكي \\
\hline $8 \% 11,2$ & rI & $\%$ Y, 1 & 09 & $\%$ ir, & rV & $\% 19,7$ & or & جبنته & | \\
\hline$\% 1,1$ & To & $\% 10,4$ & $\varepsilon r$ & $\%\urcorner, 2$ & iv & $\% 0,1$ & 17 & تل & Wle \\
\hline$\% ?, \wedge$ & is & $\% 0,1$ & 18 & $\%\{\cdot, \varepsilon$ & 1.9 & $\% \circ r, \lambda$ & 106 & نتير & نغ \\
\hline$\%$ \% & vi & $\% T q, Y$ & 1.7 & $\% \varepsilon, 0$ & IT & $\% \vee, \wedge$ & $r$ & إلمابي & إغير لميلمابي \\
\hline$\% 10,0$ & \&Y & $\% 19,7$ & or & $\% Y, Y$ & II & $\% 4, \wedge$ & YV & تابع & تَبت: \\
\hline$\% q, 1$ & ro & $\% \vee, A$ & YI & $\% 11,0$ & or & $\%$ \%१, & A. & خديفت & تمري \\
\hline$\% 10,0$ & $\& Y$ & $10, Y$ & $\varepsilon r$ & \%rT, & $7 \varepsilon$ & $\%$ Yr,o & 15 & نج & لطين \\
\hline$\% r \leqslant, 0$ & ar & $\% r o, r$ & 17 & $\% 9,0$ & ד & $\%$ ir, & ry & بدائى & |متحضر \\
\hline$\% r, r$ & 7 & $\% \cdot$, & • & $\% 0 \cdot .0$ & IrV & $\% \leq r, 1$ & IIV & جاهل & 8 \\
\hline
\end{tabular}




\begin{tabular}{|c|c|c|c|c|c|c|c|c|c|}
\hline \multicolumn{4}{|c|}{ الإجليكت السلينية } & \multicolumn{4}{|c|}{ الإجليلت الاربجلية } & \multirow{3}{*}{\multicolumn{2}{|c|}{ الصغــــــت }} \\
\hline \multicolumn{2}{|c|}{ طلب لليضي } & \multicolumn{2}{|c|}{ طلب أسود } & \multicolumn{2}{|c|}{ طلب أيبض } & \multicolumn{2}{|c|}{ طلب أسرد } & & \\
\hline التسبة & العدد & التنببة & العيد & النسبة & العدد & التسينة & تلعد & & \\
\hline$\% 1 \cdot, 9$ & $r$. & $\%$ ir, Y & rs & $\% ı r, Y$ & r & $\% 11,1$ & rr & عيير محبرب & | محبرب \\
\hline$\% \times 4,1$ & va & $\% \leq 1, Y$ & $11 r$ & $\%\lfloor, 1$ & 11 & $\% 0,9$ & 17 & ضد الأمريكيين & الأمريكينين \\
\hline$\%$ \%Y,. & $\mathrm{ve}$ & $\% r a, r$ & 1.1 & $\% 0,9$ & 17 & $\%, r, Y$ & rv & متطرن & | مستل \\
\hline$\% r r, T$ & Is & $\% \times 9,2$ & A. & $\% \backslash 1,0$ & $r q$ & $\%, r, \lambda$ & $r v$ & كمول & | تشيط \\
\hline$\% Y, Y$ & $Y$ & $\% \mathrm{Y}, \mathrm{A}$ & ri & $\%$ \%r, & $\wedge \wedge$ & $\% r o, r$ & 97 & تنز & نظفينت \\
\hline$\% r 1, \lambda$ & 09 & $\% r r, r$ & 9. & $\% Y, Y$ & YI & $\%, r, Y$ & $r v$ & مولع بالحرب & صب الملاتم \\
\hline
\end{tabular}

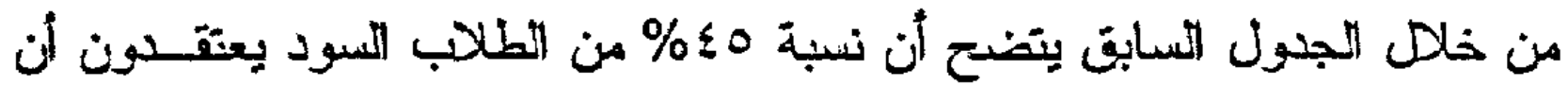

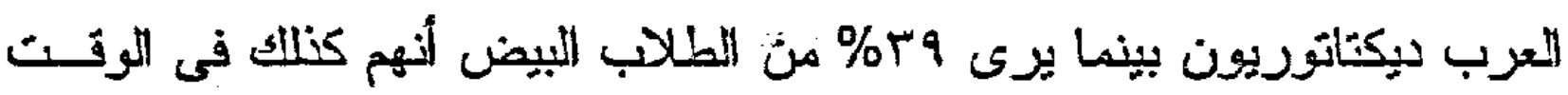

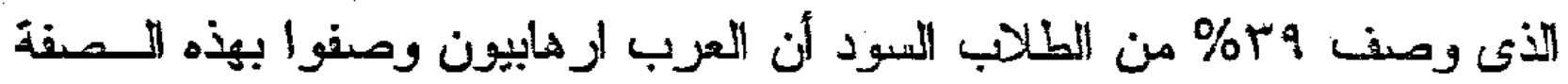

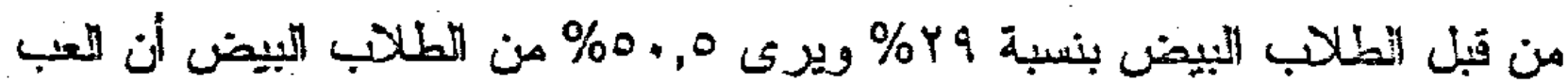

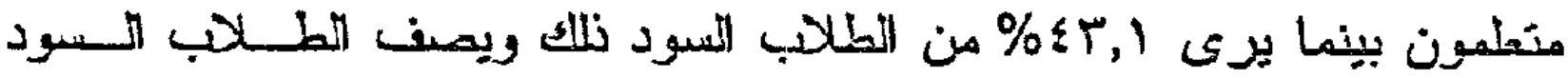

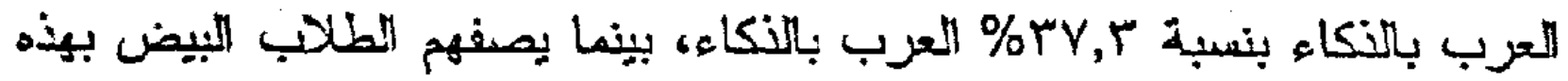
\% ro,0 المنة بنسبة

وقام اللباحث بإجراء اختبار (ت) لاختبار وجود فزون ذات دلالة إحصائية بسين الطلاب البيض والماللب السود فى اتجاهاتهم نحو للعرب، يوفحه الجبول رقم 


\section{جدول رقم (a)}

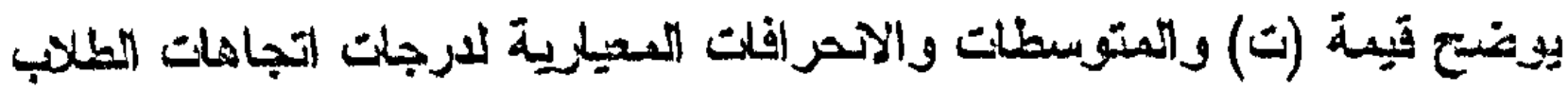

وفتا لمتنتز

\begin{tabular}{|c|c|c|c|c|c|c|}
\hline dy+l & قيمة اختبلر & لy & الالهمران & اللمنتوبسط & المحد & التمت \\
\hline \multirow[t]{2}{*}{$\cdot, \lambda \leqslant q$} & \multirow[t]{2}{*}{.191} &., 7.00 & $\cdot, E Y Y \& Y$ & $r . \cdot 1 Y V$ & 01 & 2 \\
\hline & & $\cdot, T Y I E$ & $\bullet, Y Y \wedge \leq 1$ & $T, . . . r$ & YY. & ن \\
\hline
\end{tabular}

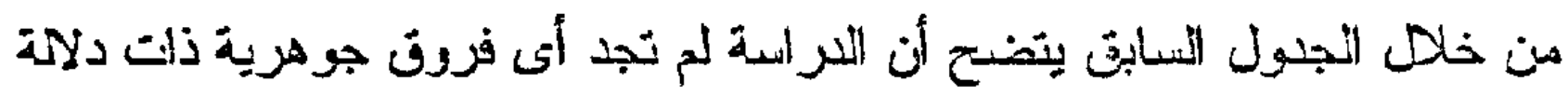

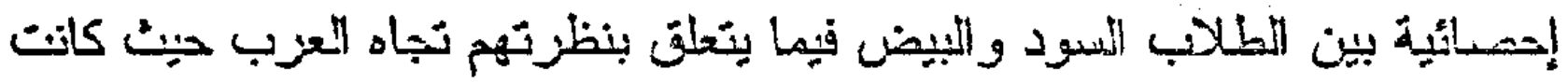

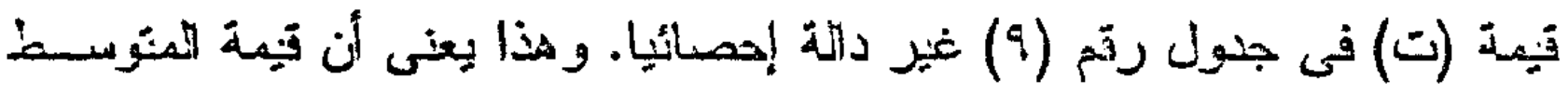

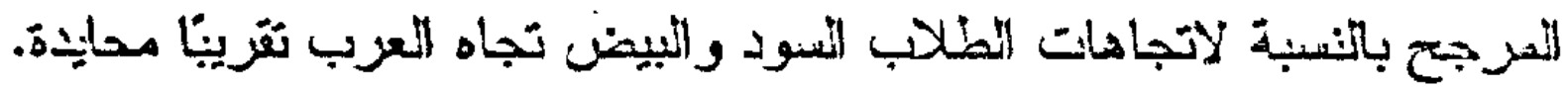

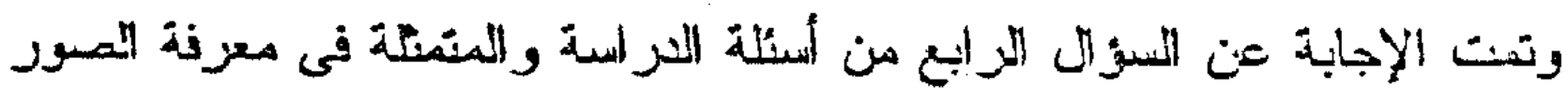

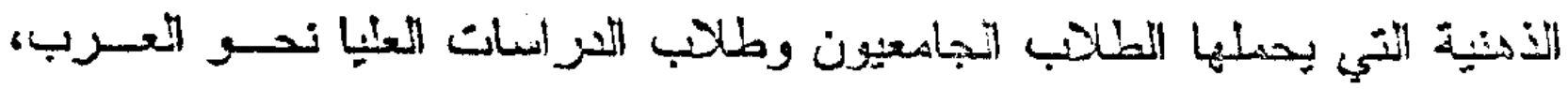

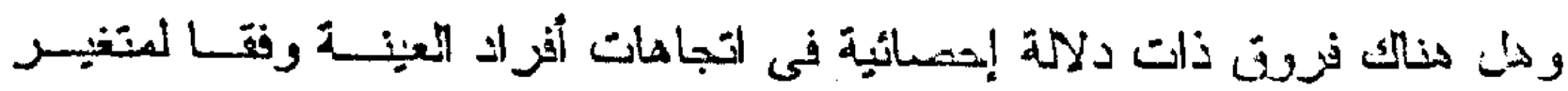

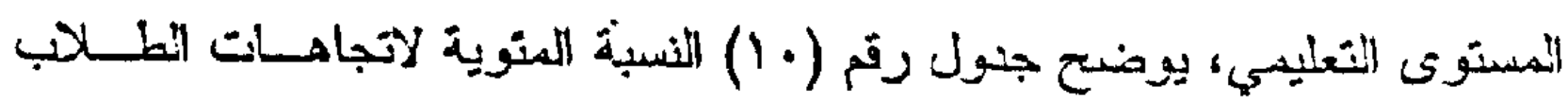

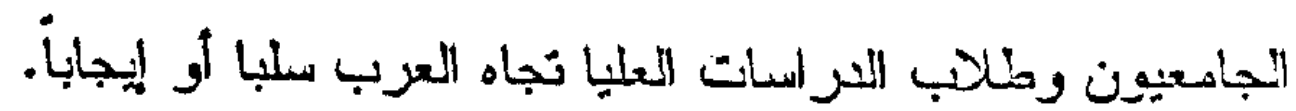




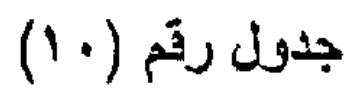

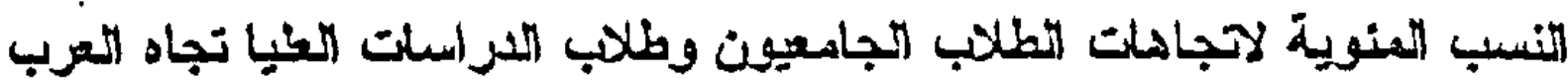
سئبا أو ايجناً.

\begin{tabular}{|c|c|c|c|c|c|c|c|c|c|}
\hline \multicolumn{4}{|c|}{ الاجليك السليرة } & \multicolumn{4}{|c|}{ الإجلجيت الإجلير2 } & \multirow{2}{*}{\multicolumn{2}{|c|}{ "لمنات }} \\
\hline عم & & t & & & & ك عبا & برا & & \\
\hline لانسبة & لعد & التسبة & العد & لتنسبة & لاعدد & النسبة & التعدد & & \\
\hline$\% 1 .$, & $r Y$ & $\% \gamma, \varepsilon$ & $r$. & $\% 7, r$ & IY & $\% 19,1$ & $0 \leqslant$ & غِير أمين & أمين \\
\hline$\%)$ \% & $\varepsilon 7$ & $\% 1,9$ & YY & $\% r \cdot, 0$ & 07 & $\% r r, 1$ & $\Lambda V$ & لعيم & جين \\
\hline$\% Y_{1} 9$ & ri & $\% \vee, \xi$ & $Y$. & $\% \backslash A, \varepsilon$ & $\Delta$. & $\%$ \%r, & $7 \varepsilon$ & سى، & جيذ \\
\hline$\% \leq 7, \Gamma$ & Iro & $\% r 0,9$ & v. & $\% 7, \lambda$ & in & $\%)\{, \wedge$ & $\varepsilon$ & ليكتاتور & يستزاطي \\
\hline$\% 17, r$ & $\{\mathfrak{q}$ & $\% i r, r$ & rr & \%rt, r & זיר & $\% r \lambda, r$ & $1 . \varepsilon$ & ثخبي & نكي \\
\hline$\% 17, r$ & $\mathfrak{\varepsilon}$ & $\% \pi, Y$ & iv & $\% 1 Y, 7$ & $r \varepsilon$ & $\%) 9,1$ & of & جبان & مُجاع \\
\hline$\% i r, Y$ & $r$ & $\% r, v$ & 1. & $\% 7, r$ & iv & $\% 7, Y$ & iv & خُتْ & علان \\
\hline$\% Y, 1$ & YI & $\% r, Y$ & 1. & $\% \varepsilon \cdot$, & 1.1 & $\% \circ 1, \lambda$ & $1 \leqslant$. & نقيز & 2iنى \\
\hline$\% r o, r$ & 90 & $\%$ \% , . & or & $\% r, r$ & 9 & $\% १, 9$ & $\overline{r y}$ & الدمابي & غير المدابيى \\
\hline$\% 19.0$ & or & $\% \wedge, 7$ & $r r$ & $\% \Delta, \lambda$ & 17 & $\% \backslash T, 1$ & $r v$ & تابيع & 5it \\
\hline$\% 1 .$, & $r v$ & $\% 7, Y$ & iv & $\% \backslash \wedge, q$ & 0. & $\% \curlyvee \lambda, \varepsilon$ & VV & حنسين & كوي \\
\hline$\%, Y, \varepsilon$ & $\xi V$ & $\% 11,1$ & $r$. & $\%$ \%, 1 & or & $\% \curlyvee 9,4$ & A. & نج & لطين \\
\hline$\%\{\cdot, \cdot$ & 1.1 & $\% Y Y, Y$ & 7. & $\% \gamma_{1} 9$ & $r$ & $\% 17,1$ & $\varepsilon q$ & بدائى & متحفر \\
\hline
\end{tabular}




\begin{tabular}{|c|c|c|c|c|c|c|c|c|c|}
\hline$\% r, 7$ & Y & $\% \cdot$, & - & $\%: r, Y$ & $11 x$ & $\% \pi, Y$ & 178 & جاهن & متعلم \\
\hline$\% 1 r, r$ & ri & $\% \vee, \&$ & $r$. & $\% 11,7$ & r & $\% 17$, & $\{r$ & غيز محبوب & محيرب \\
\hline$\%$ \% , r & 1.1 & $\%, \vee, r$ & $\varepsilon V$ & $\% \leqslant, r$ & 11 & $\% \varepsilon, q$ & $\pi$ & ضد الأمريكيين & الأمريكيين \\
\hline$\% r \leq, Y$ & $1 \varepsilon$ & $\%(r, 1$ & rv & $\% 0, r$ & $1 \varepsilon$ & $\% \backslash r, r$ & r & متطرت & معتلل \\
\hline$\%$ \% , 2 & YY & $\% 17$. & $\leq r$ & $\% 11,7$ & $r$ & $\%$ \%l, & or & كسول & نشيط \\
\hline$\% Y, q$ & ri & $\% \vee, \leqslant$ & $r$. & $\% \vdash 4,0$ & $\Lambda$. & $\% \varepsilon=, Y$ & 11. & قَنر & نُّين \\
\hline$\% r \cdot, \cdot$ & $\wedge 1$ & $\% 9,4$ & rr & $\% 7, r$ & iv & $\%) \leqslant, \lambda$ & $\varepsilon$. & مرلع بالمرب & يحب ألسلحم \\
\hline
\end{tabular}

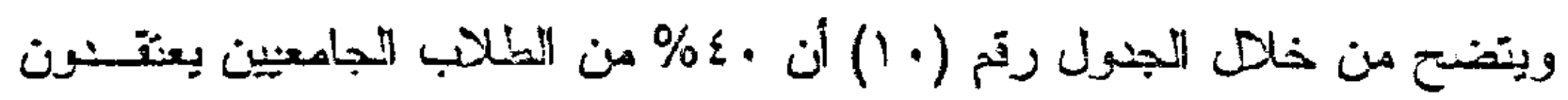

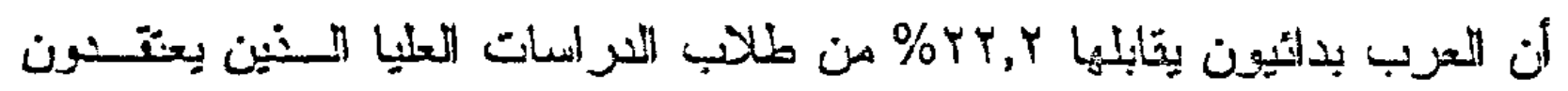
.

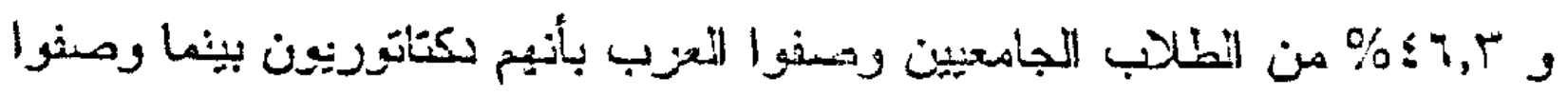

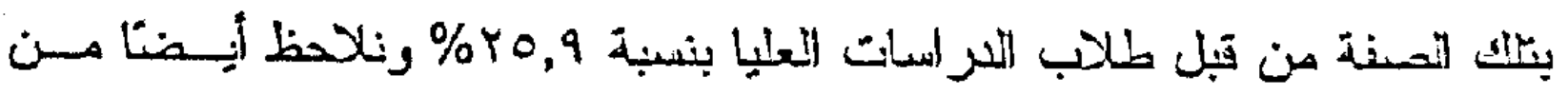

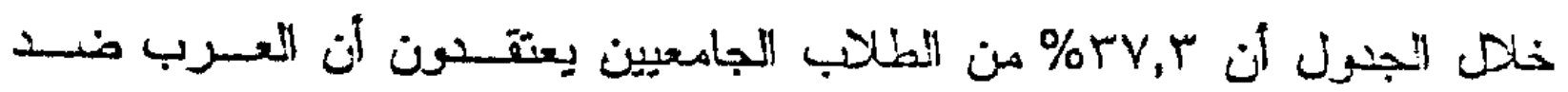

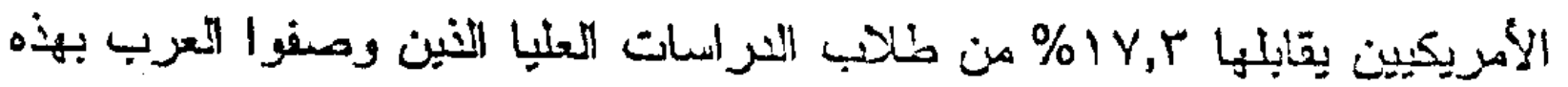


لاختبار صحة القزض الرابيع الأى نص على وجود فزوق دالة إحسـصائيا فـى

اتجاهات الطلابب نحو العرب، وفقا لمتغير المستوى التعليمي (طالب جـاهعى دراسات عليا) استخدام الباحث اختبار (ت) ويوفنح الجدول (11) هذه النتائج.

$$
\text { (11) جدول رقمة }
$$

يوضت قيهة (ت) والمتوبطلت والاتحر افلت المعيلرية

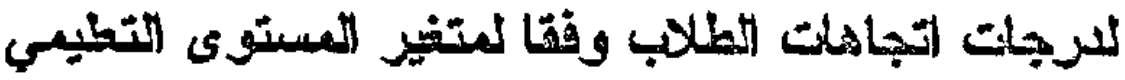

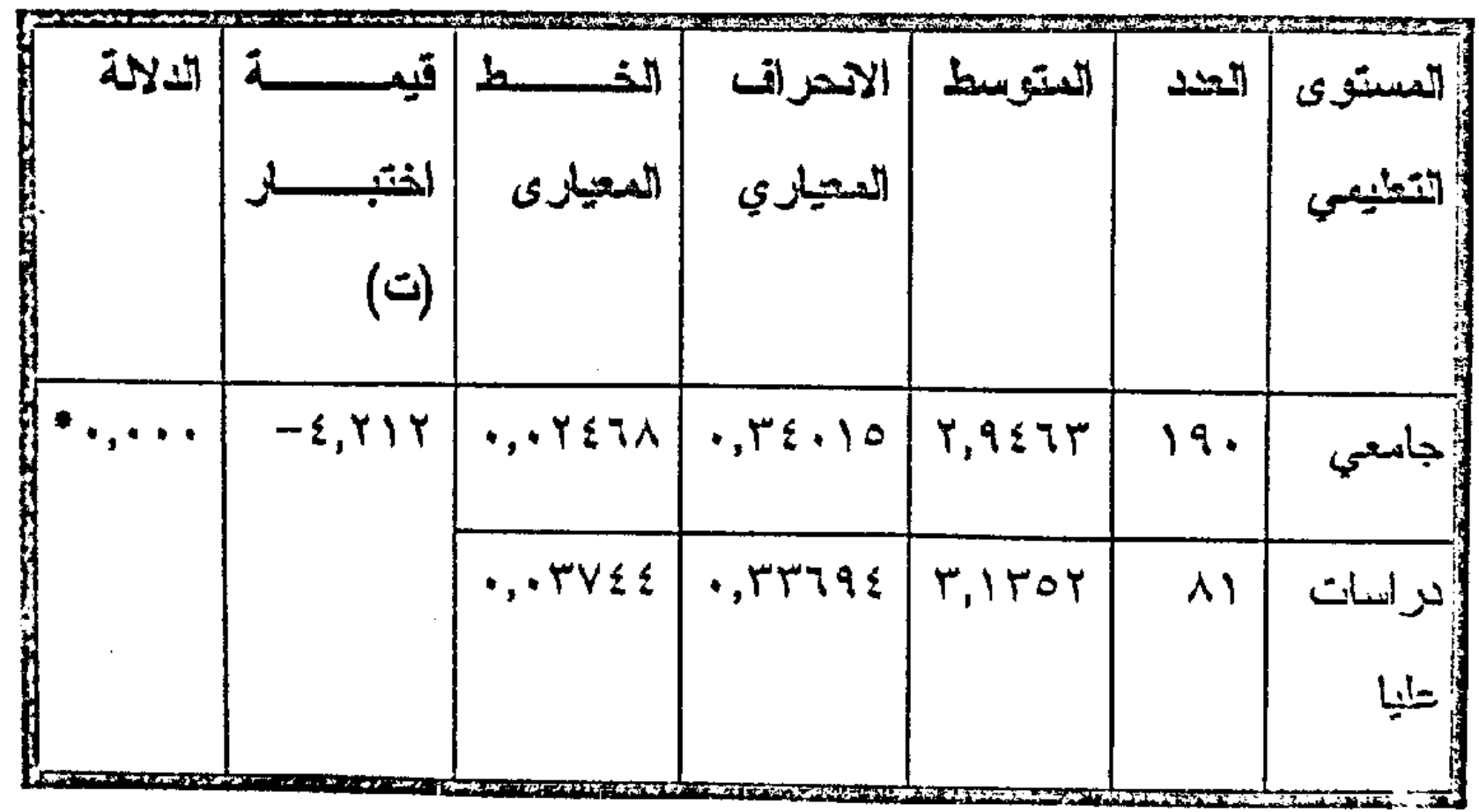

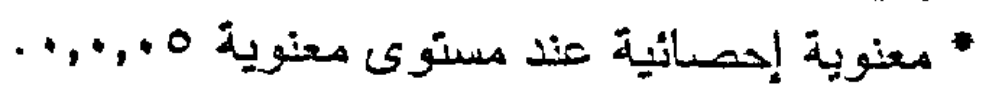

ينضتح لنا من الجذول السبابت تحقت محة الفرض الرابع حيث وجنت فرون دالة إحصائيا في منوسطات درجات اتجاهات الطلاتب الجامعيين وطلانب الدراسـات

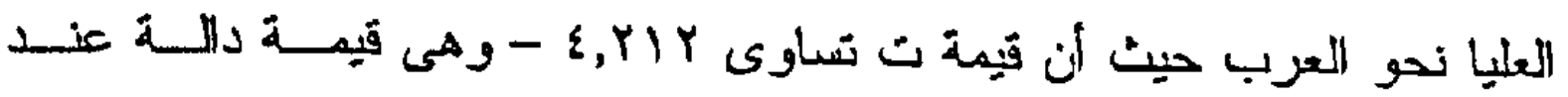

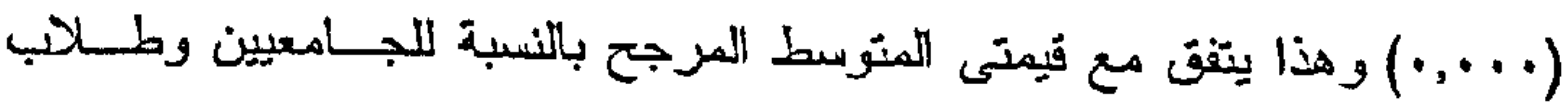


اللر اسأت العليا، حيث أتسمت نظرة المجامبيين تجاه العرب بالحيالية العلبية بينسا اتسمت نظرة طلابب الدراسات العليا لهم بالحيالية الإيجابية.

لإججابة على السؤال الخامس الذي تتاوله البحث و المتعلق من أي المصادر استقى الطلاثب دعلوماتهم عن العرب وهل هنالك فروق دالة احسمائيا بسين مــدر المعلومة واتجاهات الطلانب نحو المرب.

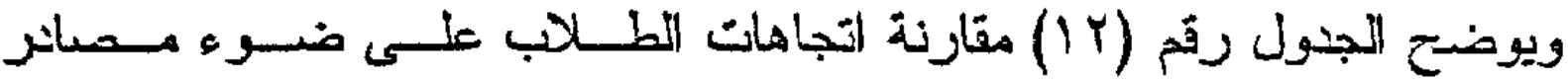
المعلومات التى السنقوا منها معرفتّم بالعرب باستخدام المتوسطات والانحرافات المبيازية لعينة النراسة.

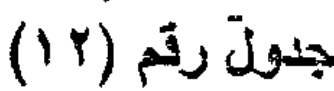

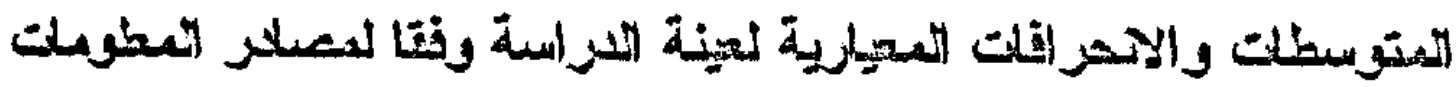

\begin{tabular}{|c|c|c|c|c|}
\hline 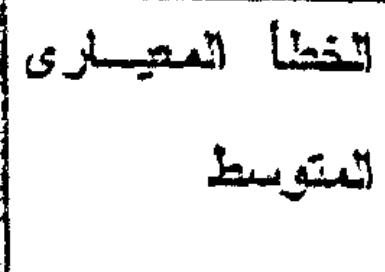 & الآمحراف & اللمتزبسط & التصد & تشسر المتزفية \\
\hline י. & TrYYYT, & $Y, q \wedge Y Y$ & $0 \leqslant$ & المجلانت \\
\hline ד דוז, & qאיזוי & Y,ATOV & 1.9 & | لتلفزيون | \\
\hline . & צדצדצי• & דrג. & 7. & | الصحافة \\
\hline -, $\leqslant \vee \vee \wedge$ & ه. & אדרותי & $\varepsilon \wedge$ & شخمى \\
\hline
\end{tabular}


One Way ولاختبار محة الفزض الستخم الباحث تحليل التبـاين الأحسادي

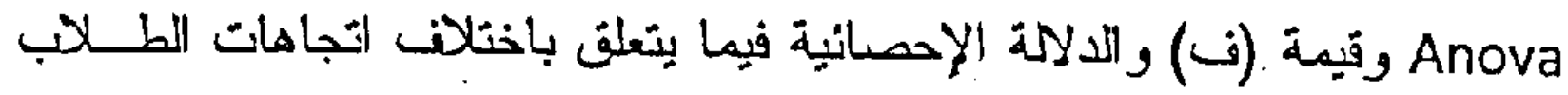
' نحو العرب ويوضحها الجنول رثم (IT) 


$$
\text { جنول رقم (IT) }
$$

One Way Anova يوضت تحليل التباين الأحادي

\section{وقيعة (ن) والادلاحة الإحصائية}

\begin{tabular}{|c|c|c|c|c|c|}
\hline الدلالة & قيمـــــا & متوبـــــال & لربرية المريكات & المربعلت & مصلر التبلين \\
\hline \multirow[t]{3}{*}{$* \ldots, \ldots$} & \multirow[t]{3}{*}{$\mid \wedge, \wedge Y \leq$} & 1,919 & r & $0, Y \circ V$ & بين المجموعات \\
\hline & & $\cdot, 1 \cdot Y$ & raY & $Y V, Y M A$ & أداخل المجموتات \\
\hline & & . & YV. & ry, ivo & \\
\hline
\end{tabular}

$$
\text { * متنوبية الحصائية عند مسنزى معنوية ه., *. }
$$

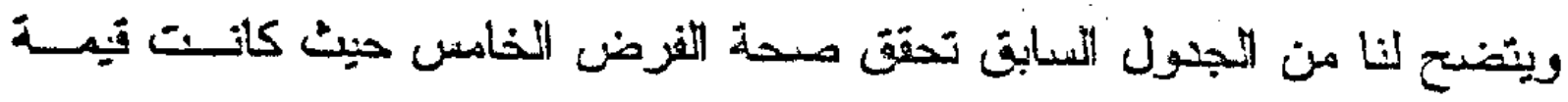
(ن) دالية، وأن هنالك فرق إمصانى معنوي بين آراء أفراد العينة حسب مصنر

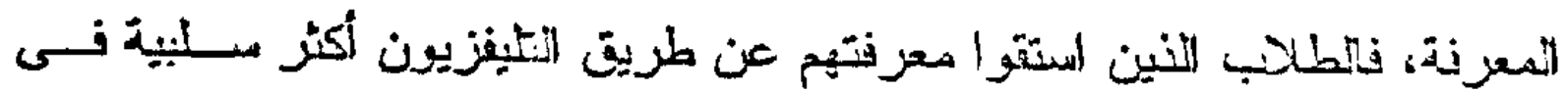

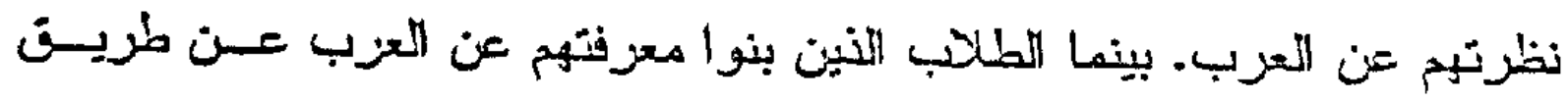

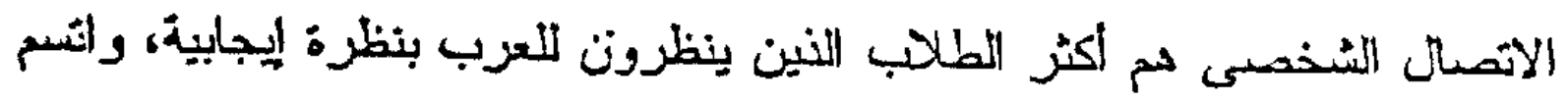

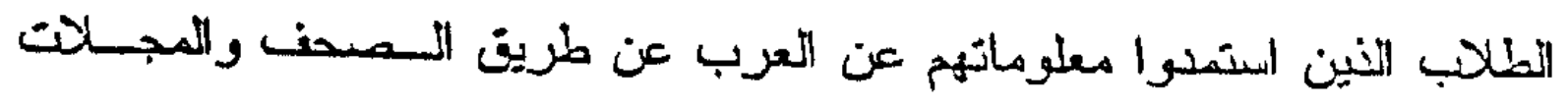
باتقرب من الحيانية التامة تجاه العزب. 


\section{التتوصيات}

فى ضوء ما أسفر عن البحثث من نتائج وحيث أن هذه اللراسة قد أجريت قبــل 11 أحداث سبتمبر Y +. بام يوصى الباحث ببعض النقاط:

ا- القتيام بعفل دراسات لتصديح مفاهيم الصور الذهني التى يحملهـا عنــا

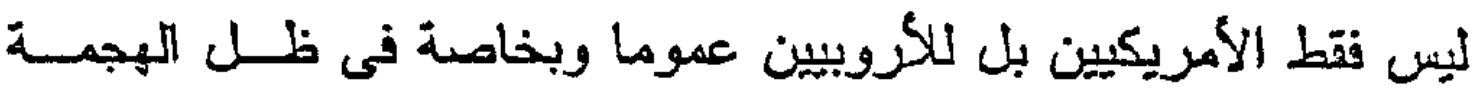

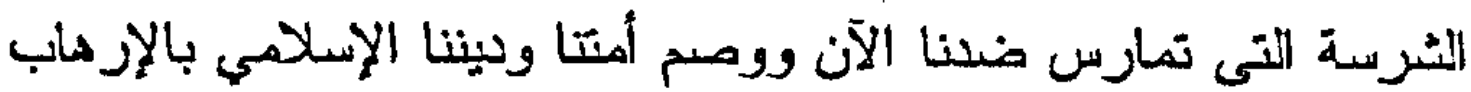
من قبل وسائل الإعلام الإجنبية. ب- اللدعم المادى والمعنوي اللا محلود من قبل الحكومات العربية لمراكـز

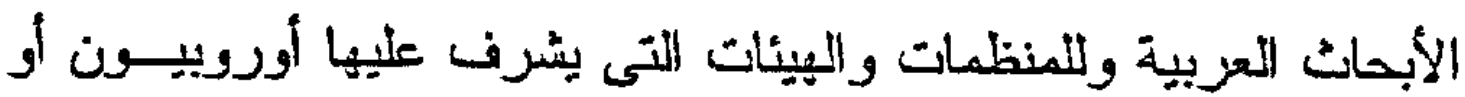
أمزيكيون من أصول عزبية.

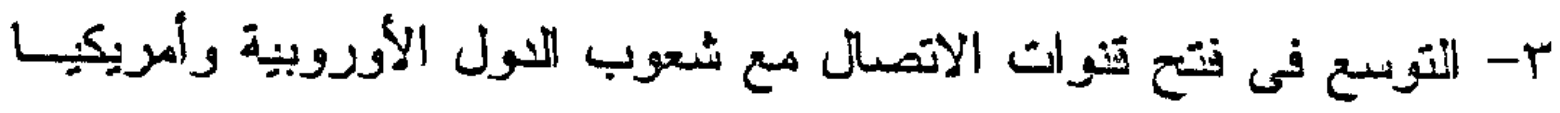
منّ ما تامت به المملكة المعربية السعودية بتوجيه من خـاتم اللحسرمين

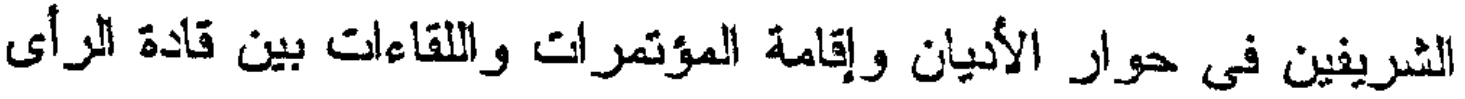
ورجال الكين الأوربيون والأمريكيون مع نظر ائهم العزب والتمسلمين.

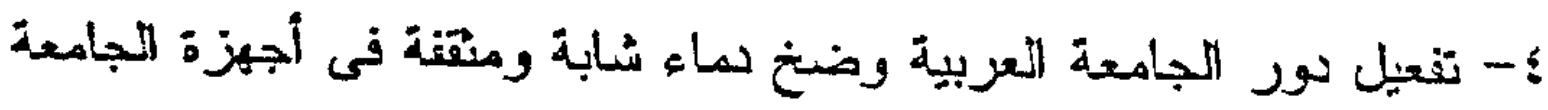

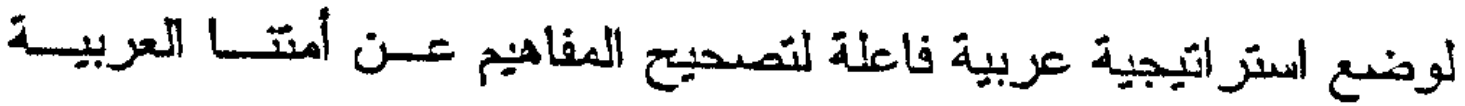
والإنلامية. 0- اللوقون المعنوى على أقل تقدير مع الأمريكيين والأوربيين المنعاطفين

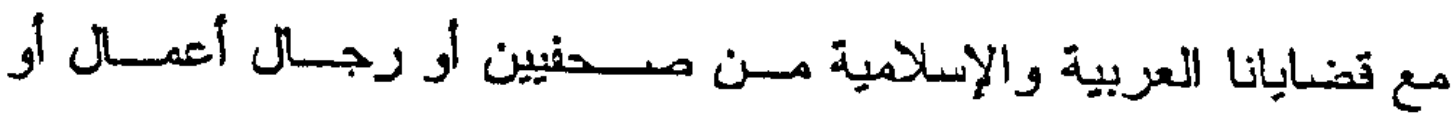
مسؤرلين متقاعدين من الخدمة. 


\section{المراجع العربية والأجنبية}

1- سبير بركات (.9A (19) الإعلام وظاهرة الصور المنطبعة، مجلة العلوم

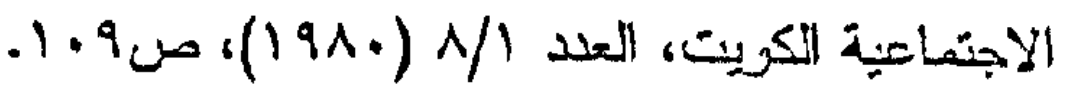

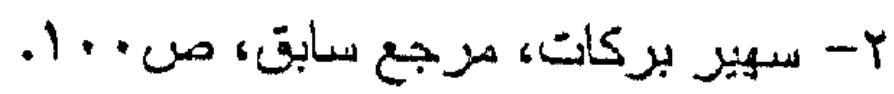

Lipman, W. (19Yr), Public Opinion. New York: Macmilla $-r$ Katz. D. \& Barly, (19rr), Rasial sterotype of one $-\varepsilon$ hundred college students. Journal of Abnormal and Social Psycholog, $Y \Lambda_{*},-Y q$.

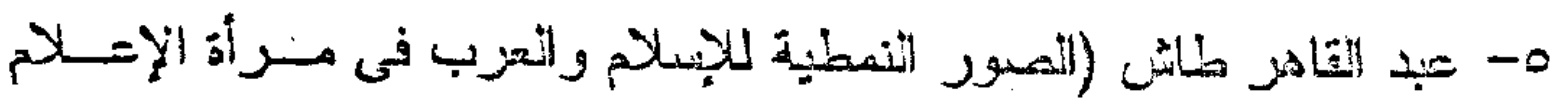

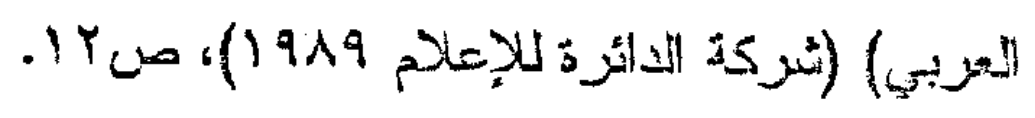

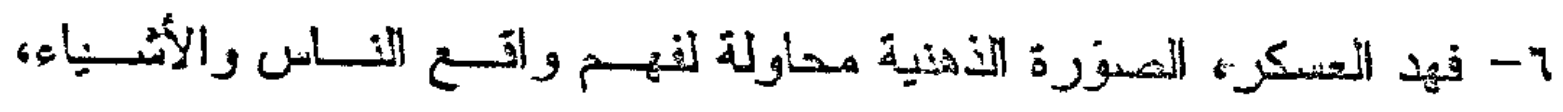

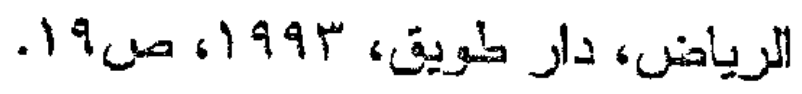

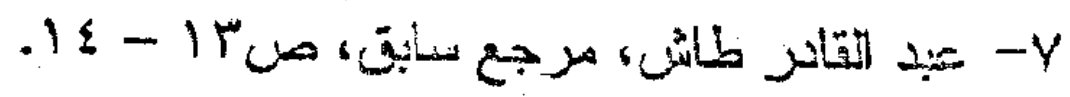

J. C Merrill, (197r), the Image of the united states in $-A$ ten Mexican Dailies, Journal Quarterly, r. r.r.

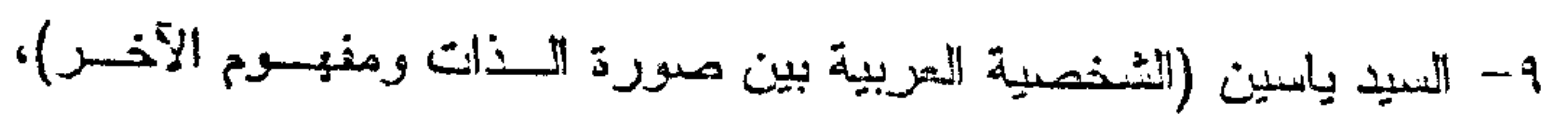

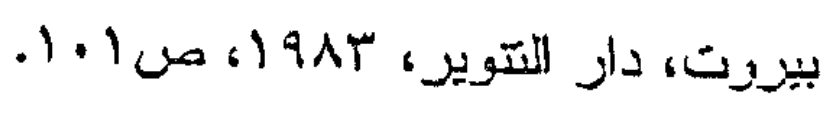

Lippman, W, IBID. Yq-).

Klineberg. $0 .(1901)$. The scientific study of national-1) stereotype international Social Sciences, Journal. r.

$$
0.0-01 \% \text {. }
$$


Brigham, J. (19vr). Ethnic stereotype and att intudell - IY Adifferent mod of analysis. Journal of personality, \&l

$$
\text { (Y). Y. T - YYr. }
$$

با-ناية سالمن صورة العرب والإســرائيليين فـى الولايــات المتحــدة

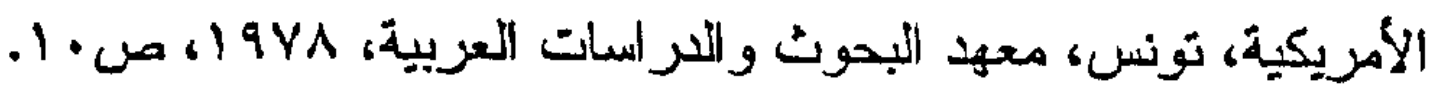
ع ا-نائية سالم، مرجع سابق. Webster's dictionary -10 Allport, G. (190\}). Survey research methods. Belmont, -1 \} CA: wads worth. IV

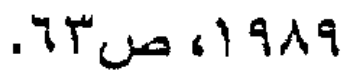

1 ا-محمد البادى، العلاقات العامة وطبيعة الز أبي العام، جذة، دار الثُروق،

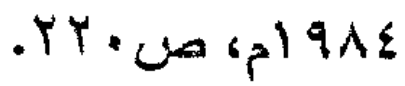

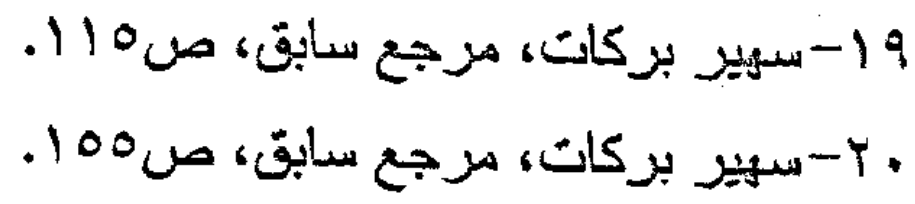

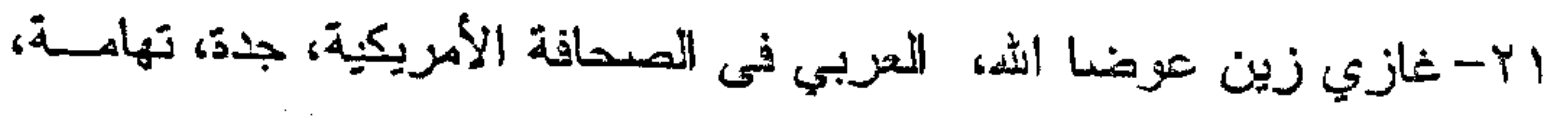
(r) Abu Zinada, Z. Y. (199 19 ) Contextualizing Arabs Image in -YY America, A Beyond content exploration. Journal Factory of Arts. Katz, D \& Braly, K. IBID-YT Allport G. IBID $-Y \leq$ Buchanan, W. \& Cantril, H. (190r), How nations see-ro each other Urbana: Univewrsity of Llinois Press. 
Boulding, K. (1907). The Image (Ann Arbor, $\mathrm{M}$ I: co-YT

University of Michingan press), pp. $\varepsilon-V$.

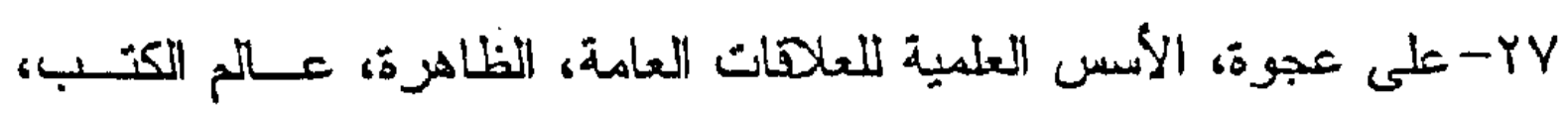

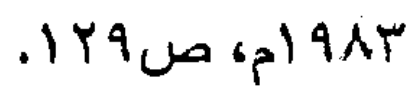

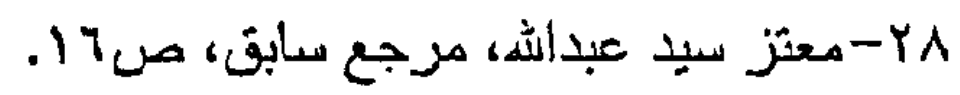
Katz \& Braly IBID - 9

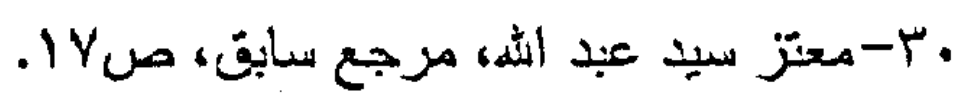
Sinha, A. \& Upadhyay, (197.) Stereotypes of male and $-r$ female University students in India to ward different ethnic groups. The Journal of Social Psychology, 01, 9r $-1 \cdot Y$.

Dewey \& Humber (1977) Change in Racial Stereotype-rY among college students. Human Relations, yo, 1.1IY.

Bich, A. (19Y૬) Interracial communication, New York-rr Harper and row.

$$
\text { ؟ }
$$

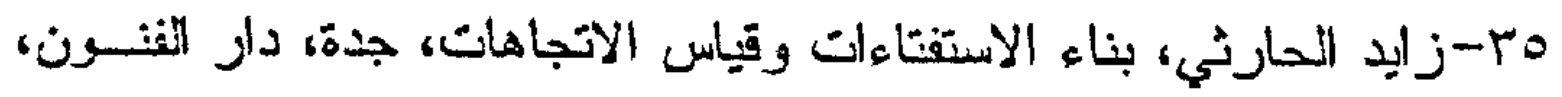
. 1994 